\title{
Dissecting the Trade Effects of Europe's Economic Integration Agreements
}

\author{
Sophie Soete \\ University of Leuven, Leuven, Belgium \\ Jan Van Hove \\ University of Leuven, Leuven, Belgium \\ KBC Group, Chief Economist Research Department, Belgium
}

\begin{abstract}
This paper systematically studies the trade effects of Economic Integration Agreements involving the European Union. We thoroughly disentangle the ex post effects of these agreements by analyzing various sources of heterogeneity and controlling for potential endogeneity and multilateral resistance. Our results confirm the general trade-enhancing impact, but point to an asymmetric effect on European exports and imports. While free trade agreements strongly increase import competition in the European Union market, their effect on European exports is much more complex. Economic Integration Agreements enhance trade by more product differentiation (the extensive margin), but reduce the trade intensity (the intensive margin) simultaneously. Nevertheless, the cumulative effect over time is positive for imports, as well as exports. Moreover, the trade effects differ across European Union member states and across agreements. In particular, the integration depth and the economic rationale matter.
\end{abstract}

\footnotetext{
* Corresponding Author: Sophie Soete; Department of Economics, University of Leuven, Naamsestraat 69 bus 3563, 3000 Leuven, Belgium, Tel: +3216326826, Fax: +3216326796, E-mail: sophie.soete@kuleuven.be.

Co-author: Jan Van Hove; Department of Economics, University of Leuven and KBC Group, Chief Economist Research Department, Naamsestraat 69 bus 3563, 3000 Leuven, Belgium, Tel: +3216376349, Fax: +3216326796 E-mail: jan.vanhove@kuleuven.be.

Acknowledgements: We would like to thank Scott Baier, Tristan Kohl, Tibor Besedes, Douglas Campbell, Ron Davies, Samuel Standaert, Benjamin Zissimos, Antoine Bouët, Anne-Gaël Vaubourg, Joep Konings, Filip Abraham and seminar participants at ETSG 2013 (Birmingham), ESRC 2015 (Keele), LETC 2015 (Izola), Fall 2015 Midwest Economics Theory and International Trade Meetings (Penn State) and the universities of Leuven and Bordeaux for helpful comments. We also thank the Flemish government for financial support.
} 
JEL Classifications: F13, F14, F15

Keywords: Trade Agreements, European Union, Gravity Model, Panel Data, Margins of Trade

\section{Introduction}

In the past two decades, the number of Economic Integration Agreements (EIAs) notified to the World Trade Organization (WTO) has exploded. Baier et al. $(2008,461)$ define EIAs as "treaties between economic units - in the case of international EIAs, between nations - to reduce policy-controlled barriers to the flow of goods, services, capital, labour, etc." Though EIAs differ in terms of integration intensity, their popularity signals that they have become the main instrument of current international economic integration. We identify four main types of EIAs in this paper, reflecting different intensities of trade integration: One-way Preferential Trade Agreements (OPTAs), Two-way Preferential Trade Agreements (TWPTAs), Free Trade Agreements (FTAs), and Custom Unions and Common Markets (CUs). In 2016 alone, six new FTAs entered into force. This brings the total number of active trade agreements notified to the WTO to a stunning 432 as of January 1, 2017. All WTO members have signed at least one trade agreement.

Not only has the number of EIAs exploded in recent years, the economic literature investigating the impact of EIAs has grown at an equal rate. This has led to tremendous improvements in methodology. While earlier studies report very mixed results on the trade effects of EIAs (for a comprehensible meta-analysis, see Cipollina and Salvatici 2010), recent studies have found more consistent results (see, e.g., Baier and Bergstrand 2007, Magee 2008, Kohl 2014, Baier, Bergstrand and Feng 2014).

In particular, the European Union (EU) has been a driving force behind the explosive growth in EIAs signed and negotiated in recent years. A substantial share of trade between the EU and the rest of the world is currently covered by EIAs, and this share will increase because of ongoing negotiations. Not counting intra-EU trade, $70 \%$ of all imports to the EU27 in 2013 and 27\% of all EU27 exports were influenced by EIAs. When we also take into account trade agreements that have not yet been enforced or are 
being negotiated, these numbers rise to $94 \%$ of imports and $63 \%$ of exports. ${ }^{1}$

Despite the EU's active role in international EIAs, surprisingly little is known about the EIAs' overall actual impact on European trade. So far, the literature has mainly focused on two alternative and related questions: first, the impact of the EU itself on intra-EU trade flows; second, the impact of specific EIAs on European trade. Given the specific characteristics of each bilateral trade relationship, the latter findings cannot be generalized. Therefore, this paper aims to fill this gap in the literature by providing a complete and systematic impact assessment of all recent EU EIAs on European exports and imports.

The two related strands in the literature provide inspiration for this goal. First, studies assessing the trade impact of the EU itself point to substantial trade-creation effects from the gradual process of European integration. Bussière, Fidrmuc, and Schnatz (2008) and Spies and Marques (2009), among others, point to large trade-creation effects from EU enlargements. The introduction of the euro has also enhanced intra-EU trade (e.g., Micco, Stein, and Ordoñez 2003, Baldwin, Frankel, and Melitz 2006, Kelejian, Tavlas, and Petroulas 2012). However, EU integration also caused trade-diversion effects for the rest of the world (Magee 2008, Geldi 2012) providing a strong rationale for international trade agreements between the EU and its trading partners.

The second related strand in the literature focuses on the impact of EU EIAs on EU trade. However, these studies are restricted to only an analysis of one or a few specific EIAs. For example, Bensassi, Márquez-Ramos, and Martínez-Zarzoso (2012) study EuroMed trade agreements between certain EU member states (France, Germany, Italy, and Spain) and four North African countries (Algeria, Egypt, Morocco, and Tunisia) for the period 1995 2008. They find that the FTAs have a positive and significant effect on the exports of the North African countries to their main European partners. Persson and Wilhelmsson (2007) study the impact of EU trade preferences for developing countries, using data on the imports of EU15 countries from developing countries over the period 1960 2002. They find that trade preferences, in general, increase exports from developing countries to the EU15 countries, but this is not the case for all preferential schemes. While the focus of Camarero, Gómez, and Tamarit (2012) is estimating the effect of the euro on the trade of 26 OECD countries, they also provide some evidence on the effects of FTAs between the EU15 and Chile, Iceland, Mexico, Norway, and South Korea. Finally, Lakatos and Nilsson (2016) quantify the impact of the 2011 EU-

\footnotetext{
'Authors' calculations based on data described in Section III.
} 
South Korea Free Trade Agreement on trade flows between the EU and South Korea.

Generally speaking, these specific studies (also called specialist studies in the literature), conclude that EU EIAs increase both imports and exports between the EU and its trading partners. These findings may, however, be driven by the specific features of each bilateral trade relationship or by differences in the applied methodology. Therefore, the quantitative effects of these specialist studies cannot be compared and generalist studies are required if one is interested in the overall effect of EIAs (Kohl 2014). Moreover, these previous studies neglect the probable interaction between trade agreements that can only be taken into account when studying the impact of all EIAs at the same time.

The specialist focus on a specific EIA obviously has merit, as it provides an insight into the agreement-specific impact. However, this approach lacks generalizability. Therefore, this paper opts for systematically analyzing the effects of EU EIAs by combining the specialist and generalist approaches. By taking a hybrid approach and combining the methodological strength of generalist studies with the sensitivity to the heterogeneity of specialist studies, we obtain sound results that are specific, yet allow for comparison.

In order to quantify these ex post effects of EU EIAs on European exports and imports, we use a panel of aggregate trade flows between 27 EU countries ${ }^{2}$ and 201 countries and territories that make up the rest of the world for the period of 1988 2013. Following the empirical approach of Baier and Bergstrand (2007), we account for the endogeneity of EIAs by including three sets of fixed effects (importer-time, exportertime and country pair).

We contribute to the literature by thoroughly disentangling the heterogeneous effects of EIAs. We do this in several different ways.

First, we not only look at the effects of EIAs on total trade flows, but we also consider whether this impact on trade flows is due to a change in the value traded of each good (the so-called intensive margin of trade) or a change in the number of goods traded (the so-called extensive margin of trade). We find that no effects on the total trade flows sometimes hide the effects on the intensive and extensive margins. Thus, both margins appear to be important in capturing the true trade effects of EIAs.

Second, we allow for differential timing of the effects by including five and ten year lags and calculating the average treatment effects. While there are already papers that

\footnotetext{
${ }^{2}$ We do not include Croatia in our sample, as Croatia became a member of the EU in mid-2013.
} 
explore the differential timing of EIA effects or the effects of EIAs on the margins, Baier, Bergstrand, and Feng (2014), Florensa, Márquez-Ramos, and Recalde (2015) and Márquez-Ramos, Florensa, and Recalde (2015) are the only papers so far that allow for the differential timing of different types of EIAs; while, at the same time, looking at the margins and controlling for the endogeneity of EIAs and multilateral resistance. ${ }^{3}$ Consistent with this literature, we find that the medium-term reaction effects are important. Longer-term effects do not seem to play a substantial role in the European context.

Third, we allow for heterogeneity across EIAs. We start by considering various types of EIAs by including separate dummies for Preferential Trade Agreements (PTAs), FTAs and CUs. Next, we also look at the trade effect of each EIA separately. We find that most EIAs increase trade flows, but the magnitude of the effects varies greatly across agreements. This is obscured when only looking at a general EIA dummy.

Fourth, we look at the different motivations for concluding EIAs and how these affect trade. Our findings indicate that the EIAs that were concluded by the EU for economic reasons stimulate trade more than those concluded for political reasons or a mix of political and economic reasons.

Fifth, we estimate the effects of EIAs on trade flows for each EU country individually. We find that the effects for most countries have the same sign. However, there is great variation in the magnitude of the effects, with such effects not being statistically significant for a substantial number of countries.

Finally, we allow for directionality of the effects of EIAs on trade flows. As expected, we find that EIAs do not have symmetric effects on imports and exports; while FTAs strongly increase import competition in the EU market, their effect on European exports is much more complex.

The remainder of this paper is organized as follows. Section II discusses the gravity model and describes our empirical methodology, while Section III discusses the data. Section IV presents the main results and findings, and Section V presents robustness checks dealing with endogeneity and changes over time in pair-specific unobservables. Section VI concludes.

\footnotetext{
${ }^{3}$ The term multilateral resistance was first introduced by Anderson and van Wincoop (2003). When modeling trade flows, it is not only important to take into account the barriers to trade between country $i$ and $j$ (bilateral resistance), but also the barriers $i$ and $j$ face when trading with all of their trading partners. Due to omitted variable bias, it is impossible to obtain accurate estimates of the effects of trade agreements on trade flows without controlling for the multilateral resistance term.
} 


\section{Methodology}

\section{A. The gravity model}

In this paper, we use a panel gravity model with three sets of fixed effects, as proposed by Baier and Bergstrand (2007) and subsequently used in a large number of studies.

Since its introduction by Tinbergen (1962), the gravity model has become the most applied model for analyzing trade flows. In its most simple form, the gravity model states that trade flows between a country pair depend negatively on the distance between the two countries and positively on the mass of each country.

During the decades following Tinbergen's seminal work, many authors have derived theoretical foundations for the gravity equation. Once a theoretical orphan, the gravity model is now a fully-fledged model with strong theoretical micro-foundations. Though estimating the trade elasticity is model-specific and different types of quantitative models (like the Armington, Krugman, Ricardian, and Melitz models) might yield different structural interpretations, Arkolakis, Costinot, and Rodriguez-Clarez (2012) argue that the gravity equation offers a common way to estimate the trade elasticity and therefore a common estimator of the gains from trade, despite the different micro-level predictions of different quantitative trade models. They adopt a broad definition of the gravity model and suggest that a trade model satisfies the gravity equation if bilateral trade flows can be decomposed as follows:

$$
\ln X_{i j t}=A_{i t}+B_{j t}+\gamma \ln \tau_{i j t}+\mu_{i j t}
$$

where $i, j=1, \ldots, N$ countries; $X_{i j t}$ denotes bilateral trade flows between country $i$ and country $j$ at time $t ; A_{i t}$ denotes the characteristics of country $i$ at time $t ; B_{j t}$ denotes the characteristics of country $j$ at time $t ; \gamma$ denotes the partial elasticity of bilateral imports with respect to variable trade costs; $\tau_{i j t}$ denotes variable trade costs and $\mu_{i j t}$ denotes parameters that are country pair-specific, but different from variable trade costs.

This general gravity model can easily be extended to accommodate a range of variables in which the researcher might be interested, thus explaining the popularity of the gravity model. A common extension is the inclusion of a dummy variable when two countries share an EIA, allowing one to evaluate the trade effects of EIAs. The gravity 
equation then takes the following form:

$$
\ln X_{i j t}=A_{i t}+B_{j t}+\gamma \ln \tau_{i j t}+\vartheta E I A_{i j t}+\mu_{i j t}^{\prime}
$$

with $\vartheta$ denoting the trade effect of EIAs.

\section{B. Pitfalls of the gravity model}

Estimating Equation (2) in order to recover $\vartheta$ might seem fairly simple. There are, however, several econometric problems that have to be addressed when estimating the gravity equation empirically.

First, and most importantly for this paper, the EIA dummy suffers from an endogeneity problem. This potentially biases the gravity model when standard estimation methods are used. Contrary to what is normally assumed in empirical papers, the EIA dummy variable is not an exogenous variable: country pairs that conclude trade agreements are not randomly selected, but unobserved time-invariant bilateral variables that simultaneously influence the presence of an EIA and the volume of trade. This endogeneity problem is extremely troublesome, as a consensus in the literature as to the direction of the bias does not exist. Baier and Bergstrand (2007) find that unobserved heterogeneity biases the coefficients of FTAs downwards in standard gravity equation estimations, while Magee (2003) builds on the natural trading partner hypothesis and argues that countries tend to conclude EIAs if they already have significant bilateral trade. This argument is consistent with Roy (2012), who finds that most positive and significant estimates of FTAs can be explained by positive selection of country pairs in trade agreements. The CUs in Roy's study, however, seem to be robust to the selection of observables. If anything, there is a negative selection effect of CUs.

Even though this endogeneity problem was already raised in Trefler (1993), Baier and Bergstrand $(2002,2004)$ and Magee (2003) were the first to address it empirically by using instrumental variables with cross-sectional data. However, due to the lack of reliable instruments, these studies have not been very successful in solving the endogeneity of EIAs, providing "at best mixed evidence of isolating the effect of FTAs on trade flows," as stated by Baier and Bergstrand (2007, 74).

Using panel data, Baier and Bergstrand (2007) provide a more convincing solution to the endogeneity problem. Panel data are extremely useful in the presence of unobserved 
time-invariant heterogeneity, as it is possible to control for this unobserved heterogeneity and hence, alleviate the endogeneity bias by using either country pair-fixed effects or differencing the data. Since then, both solutions have been extensively used in empirical works. Baier and Bergstrand use five-year intervals to difference their data, instead of the usual first differences, while Anderson and Yotov (2011) use four-year intervals. This is because trade flows typically change very slowly over time, making it extremely likely that first-differenced data will not display much variation. We henceforth call these fifth and fourth differences, respectively.

Differencing panel data has one major advantage over using fixed effects: if the error terms are highly serially correlated, then estimating the model in differences will be more efficient than fixed effects for large $T$ (Wooldridge 2010). However, fourth differencing also results in a loss of data, as the fifth-differences estimator employs the first four years of data. This becomes especially problematic when adding lags to our baseline model, as it results in additional loss of data and the time span of our data is only 26 years. This is why we estimate our model using both methods (see Section V.A. for results using differenced data).

Second, $A_{i t}$ and $B_{j t}$ include the so-called Multilateral Price/Resistance (MR) term (see, e.g., Anderson and van Wincoop 2003). There are different methods to estimate this unobserved MR term (see Feenstra 2004). A first option is to proxy the multilateral MR term by price index data (like GDP deflators). However, not all costs of making transactions across borders are reflected in aggregate price indices, so this estimation method will yield biased results. A second option is to directly estimate the MR term. This requires solving a highly nonlinear system of $N$ equations with a custom nonlinear least squares program. As this is computationally very burdensome, it is not feasible for datasets with a large number of country pairs and years, such as ours. A third alternative is to include country-time fixed effects. Though still computationally burdensome when working with large panel datasets, ${ }^{4}$ this has become the preferred method of many analysts, including Baier and Bergstrand (2007), for solving the MR problem.

Third, zero trade flows are very common in trade datasets when a global perspective is adopted. When using a log-linearized gravity equation, these zero observations are ignored, which can potentially bias the results. Two methods have been proposed in the literature to cope with this zero-trade-flow problem: including a selection equation and estimating the model multiplicatively using, for example, the Poisson pseudo-maximum

\footnotetext{
${ }^{4}$ Calculation times have luckily shortened tremendously since the introduction of the high-dimensional fixed effects command reghdfe for Stata by Guimaraes and Portugal (2010), which was first used in a gravity setting in Kohl, Brakman and Garretsen (2016).
} 
likelihood estimator (PPML, as proposed by Santos Silva and Tenreyro 2006). However, due to the particular characteristics and quality of our dataset, only $34 \%$ of the trade flows in our sample contain zeroes or missing values. Moreover, it is computationally impossible to estimate a model with a large number of fixed effects using PPML because of convergence issues. Finally, Limão (2016) notes that selection due to zero trade flows is not an issue if one is only interested in the impact of EIAs on the treated group, as is the case in this paper, and believes non-traders will never form an EIA. Evidence from a meta-analysis by Cipollina and Salvatici (2010) indicates no significant differences between estimates that address the zero issue (Limão 2016).

This brings us to the following baseline model:

$$
\ln X_{i j t}=\beta_{0}+\beta_{1} P T A_{i j t}+\beta_{2} F T A_{i j t}+\beta_{3} C U_{i j t}+\delta_{i t}+\varphi_{j t}+\rho_{i j}+\varepsilon_{i j t}
$$

where $P T A_{i j t}\left(F T A_{i j t}\right)\left(C U_{i j t}\right)$ is a dummy variable taking the value 1 when countries $i$ and $j$ have an active PTA (FTA) (CU) in year $t ; \delta_{i t}$ is the importer-time fixed effect; $\varphi_{j t}$ is the exporter-time fixed effect; $\rho_{i j}$ is the country pair fixed effect and $\varepsilon_{i j t}$ is the error term.

\section{Dissecting the effects of EIAs}

Our baseline model is, however, too simple to capture the complex trade effects of EIAs. Starting from our simple baseline model, we therefore progressively dissect the heterogeneous effects of the EU EIAs in a more precise manner. Hence let go of the frequently used empirical assumption of homogeneous trade effects of EIAs (see, e.g., Rose 2000, Feenstra, Markusen, and Rose 2001, Frankel and Rose 2002). In this paper, we dissect the complexity of the effects of EIAs in six ways.

First of all, we are interested in the exact way trade agreements affect trade flows: Do EIAs affect how much of a given good is traded (the intensive margin) or rather how many goods are traded (the extensive margin)? Following Hummels and Klenow (2005), we therefore decompose our trade flows into intensive and extensive margins, using highly disaggregated data.

Second, EIAs could also have very different effects, depending on how long they have already been in place. EIAs are typically phased-in over a period of five to ten 
years, and terms-of-trade changes typically take a few years before coming into effect, thus altering the effect of EIAs over time. Following Baier and Bergstrand (2007) and Baier, Bergstrand, and Feng (2014), we estimate a distributed lags model by including five and ten year lags of our set of EIA variables in our estimations in order to pick up on these reaction effects.

Our fixed-effects specification then becomes:

$$
\begin{aligned}
& \ln X_{i j t}=\beta_{0}+\beta_{1} P T A_{i j t}+\beta_{2} P T A_{i j t-5}+\beta_{3} P T A_{i j t-10}+\beta_{4} F T A_{i j t}+\beta_{5} F T A_{i j t-5} \\
& \quad+\beta_{6} F T A_{i j t-10}+\beta_{7} C U_{i j t}+\beta_{8} C U_{i j t-5}+\beta_{9} C U_{i j t-10}+\delta_{i t}+\varphi_{j t}+\rho_{i j}+\varepsilon_{i j t}
\end{aligned}
$$

Magee (2008) goes a step further and includes a separate dummy per year, in which an EIA has entered into force. This makes it possible to evaluate how the effects of EIAs change over time. However, including this many dummy variables in our model results in unstable coefficients due to multicollinearity. Trade flows typically display some hysteresis over time, making several of these variables highly correlated.

Third, we take the dissection of the European EIAs even further and evaluate the effects of each TWPTA, FTA, and CU individually. We do this by swapping the PTA, FTA, and CU dummies with a separate dummy for each agreement (the agreements included are listed in Appendix 1).

Fourth, we dissect EIAs even further by analyzing the impact of different motivations for concluding trade agreements on trade flows. We do this by re-categorizing our EIA dummies and adding them into our baseline model.

Fifth, we take a closer look at the effects of the EU EIAs on each EU country individually. EU EIAs are negotiated by the EU, but they may not have a similar impact on all member states. The 27 economies of the EU differ considerably and EIAs can have very different economic effects, depending on the characteristics of the signatories. We therefore estimate our baseline model for the EU countries individually.

Following Herderschee and Qiao (2007), we do this by creating three sets of interaction terms with, on the one hand, our EIA dummies and, on the other hand, a dummy for the country for which we estimate the individual effect.

Our fixed-effects specification then becomes:

\footnotetext{
${ }^{5}$ Dür, Baccini and Elsig.(2014) coded 587 agreements signed between 1945 and 2009, and find that it takes on average 5.7 years for the tariff cuts of an FTA to be fully implemented and 4.5 years for a CU. Partial trade agreements have a relatively short, so-called, "transition period" of just 1.7 years.
} 


$$
\ln X_{i j t}=\beta_{0}+\beta_{1} P T A_{i j t} * I_{j}+\beta_{2} F T A_{i j t} * I_{j}+\beta_{3} C U_{i j t} * I_{j}+\delta_{i t}+\varphi_{j t}+\rho_{i j}+\varepsilon_{i j t}
$$

where $I_{j}$ is the indicator variable for country $j$.

Finally, we consider the directionality of effects. Most papers analyzing the effects of EIAs, including Baier, Bergstrand and Feng (2014) and Kohl (2014), implicitly assume that the effects of EIAs on imports and exports are symmetric. In this paper, we allow EIAs to have different effects on import and export flows. We do this by interacting our EIA dummies with a dummy variable indicating whether the 27 EU countries are trading with other EU countries, importing from non-EU27 countries or exporting to non-EU27 countries.

\section{Data}

The data used in this paper cover bilateral trade flows between the 27 member states of the EU and the rest of the world (201 countries and territories) from 1988 through 2013. Appendix 2 lists the countries included in our dataset.

We have two main datasets. Data on bilateral trade flows come from COMEXT, the Eurostat database. We opted for this database as it contains the most detailed and complete information on trade between each EU country and the rest of the world: both intra- and extra-EU imports and exports are available at the eight-digit level from 1988 to 2013 for a large number of countries.

For our dataset on trade agreements, we constructed a multichotomous index of EIAs. We used the same EIA classification as Baier and Bergstrand (based on Frankel 1997 and Balassa 1987), but since the EU did not conclude any Economic Union Agreements and because of the small number of TWPTAs, we compiled the Baier and Bergstrand index into three categories: (1) OPTA and TWPTA (PTAs), (2) FTAs and (3) CUs. Data on FTAs and CUs were collected from McGill (2014), Tuck (2014), WorldTradeLaw.net (2013), WTO (2014), EFTA (2014), and the European Commission (2014). Appendix

\footnotetext{
${ }^{6}$ The COMEXT database considers Belgium and Luxembourg, and Liechtenstein and Switzerland, as single countries. So, when we refer to Belgium or Switzerland in this paper, we really mean Belgium and Luxembourg, and Switzerland and Liechtenstein.

${ }^{7}$ When data on the entry into force of agreements exceptionally differed between sources, we used the data provided by the European Commission. Comparing our EIA data to the EIA data collected by Baier and Bergstrand (and available at www.nd.edu/ jbergstr) reveals a high intercoder reliability: we obtain $91 \%$ agreement between both datasets and a Krippendorph's Alpha of 0.85 .
} 
1 lists all the EU FTAs and CUs with the rest of the world. For data on PTAs, we used Council Regulations (1987, 1988, 1994, 1998, 2001, 2005, 2008, and 2012) of the EU concerning the Generalised Scheme of Preferences (GSP) and European Commission (2014) as our main sources. Summary statistics of the EIAs are provided in Table 1.

Table 1. Summary statistics

\begin{tabular}{|l|c|c|c|}
\hline Agreement & Frequency & Percentage & Share of EIAs \\
\hline No Economic Integration Agreement & 80,515 & 44 & \\
\hline One-way Preferential Trade Agreement & 57,259 & 31 & 56 \\
\hline Two-way Preferential Trade Agreement & 6,763 & 4 & 7 \\
\hline Free Trade Agreement & 24,778 & 14 & 24 \\
\hline Customs Union and Common Market & 12,999 & 7 & 13 \\
\hline Total & $\mathbf{1 8 2 , 3 1 4}$ & $\mathbf{1 0 0}$ & $\mathbf{1 0 0}$ \\
\hline
\end{tabular}

(Note) Summary statistics refer to the observed trade flows in the dataset.

(Source) Authors' calculations.

\section{Main Results}

\section{A. Baseline model}

Table 2 represents estimates of the partial equilibrium effects of different types of EIAs on trade flows based on Equation (3). As the Breusch-Pagan test and the Wooldridge test indicate the presence of severe heteroskedasticity and serial correlation in the data, respectively, we employ standard errors that are clustered two-ways: namely, by country pair and year.

First of all, note that the EU has only concluded three customs unions (Andorra, Turkey, and San Marino) and three common market agreements (Liechtenstein, ${ }^{8}$

\footnotetext{
${ }^{8}$ We ignore the common market agreement between Liechtenstein and the EU, as Liechtenstein and Switzerland are considered one country in our dataset.
} 
Norway, and Iceland) with the rest of the world. Results for the CU dummies will therefore mainly be driven by Turkey, Norway, and Iceland, and they will have large standard errors due to the small sample size.

From the first column of Table 2, we find that deeper integration agreements have larger effects on trade flows. This is consistent with Baier, Bergstrand, and Feng (2014), who also find that FTAs and CUs have larger average effects on trade flows than PTAs, and CUs have larger effects on trade than FTAs and PTAs.

We find that PTAs do not have a statistically or economically significant impact on trade flows. This is surprising, as the goal of most EU PTAs is to increase imports from (poor) extra-EU countries to the EU. However, there is some evidence that exports eligible for preferential treatment do not always enter the EU market at a preferential rate due to, for example, complex rules-of-origin procedures (see, e.g., Manchin 2006 for a discussion of the preference utilization rate of African, Caribbean, and Pacific countries). This unexploited potential of PTAs might explain why they have not succeeded in significantly raising imports to the EU.

We find a different result based on the estimates for FTAs and CUs. These trade agreements have a statistically significant impact on total trade flows, increasing them on average by $e^{(0.20)}-1=22 \%$ and $63 \%$, respectively.

\section{B. Key role for the extensive margin}

Each set in Table 2 presents the results of applying the same specification with three alternative dependent variables: bilateral import or export flows ( $X$ or $\ln X_{i j t}$ in Equation (3)), the intensive margin ( $I M$ or $\left.\ln I M_{i j t}\right)$ and the extensive margin (EM or $\left.\ln E M_{i j t}\right)$.

We find that the extensive margin plays an important role for all three types of EIAs. Even though we did not find any effect of PTAs on total trade flows, we do find that PTAs have a positive and statistically significant effect on the extensive margin, and they increase the variety of goods traded. This trade diversification effect is, however, offset by an equally large, but negative effect on the intensive margin: we find that the value traded per good decreases.

For FTAs and CUs, we also find an increase in the extensive margin. This increase, however, is not offset by the intensive margin effects, resulting in positive total trade flow effects. 


\section{Table 2. Baseline model}

(GLS estimation using three sets of fixed effects)

\begin{tabular}{|c|c|c|c|c|c|c|c|c|c|}
\hline \multirow{2}{*}{$\begin{array}{l}\text { Independent } \\
\text { variables }\end{array}$} & \multicolumn{3}{|c|}{ Set (1) } & \multicolumn{3}{|c|}{ Set (2) } & \multicolumn{3}{|c|}{ Set (3) } \\
\hline & $\mathbf{X}$ & IM & EM & $\mathbf{X}$ & IM & EM & $\mathbf{X}$ & IM & EM \\
\hline PTA & $\begin{array}{c}0.02 \\
(0.050)\end{array}$ & $\begin{array}{c}-0.18^{* * *} \\
(0.067)\end{array}$ & $\begin{array}{l}0.20^{* * * *} \\
(0.056)\end{array}$ & $\begin{array}{c}0.01 \\
(0.050)\end{array}$ & $\begin{array}{l}-0.18^{* *} \\
(0.070)\end{array}$ & $\begin{array}{c}0.19^{* * *} \\
(0.058)\end{array}$ & $\begin{array}{c}0.07 \\
(0.053)\end{array}$ & $\begin{array}{l}-0.15^{*} \\
(0.071)\end{array}$ & $\begin{array}{l}0.21^{* * *} \\
(0.070)\end{array}$ \\
\hline Lag5 & & & & $\begin{array}{l}0.08^{* *} \\
(0.040)\end{array}$ & $\begin{array}{c}-0.03 \\
(0.044)\end{array}$ & $\begin{array}{l}0.12 * * * \\
(0.034)\end{array}$ & $\begin{array}{c}0.08^{*} \\
(0.042)\end{array}$ & $\begin{array}{c}-0.04 \\
(0.045)\end{array}$ & $\begin{array}{l}0.12 * * * \\
(0.037)\end{array}$ \\
\hline $\operatorname{Lag} 10$ & & & & & & & $\begin{array}{c}0.06 \\
(0.043)\end{array}$ & $\begin{array}{c}-0.01 \\
(0.048)\end{array}$ & $\begin{array}{c}0.07 \\
(0.041)\end{array}$ \\
\hline FTA & $\begin{array}{l}0.20^{* *} \\
(0.079)\end{array}$ & $\begin{array}{c}-0.11 \\
(0.087)\end{array}$ & $\begin{array}{l}0.31^{* * *} \\
(0.082)\end{array}$ & $\begin{array}{l}0.20^{* *} \\
(0.075)\end{array}$ & $\begin{array}{c}-0.1 \\
(0.088)\end{array}$ & $\begin{array}{c}0.30 * * * \\
(0.082)\end{array}$ & $\begin{array}{l}0.23^{* *} \\
(0.089)\end{array}$ & $\begin{array}{c}-0.05 \\
(0.095)\end{array}$ & $\begin{array}{l}0.28^{* * *} \\
(0.092)\end{array}$ \\
\hline Lag5 & & & & $\begin{array}{c}0.09 \\
(0.053)\end{array}$ & \begin{tabular}{|c}
-0.09 \\
$(0.051)$
\end{tabular} & $\begin{array}{l}0.17^{* * *} \\
(0.045)\end{array}$ & $\begin{array}{c}0.10^{*} \\
(0.056)\end{array}$ & $\begin{array}{c}-0.08 \\
(0.061)\end{array}$ & $\begin{array}{l}0.18^{* * *} \\
(0.050)\end{array}$ \\
\hline Lag10 & & & & & & & $\begin{array}{c}0.02 \\
(0.043)\end{array}$ & $\begin{array}{c}-0.02 \\
(0.053)\end{array}$ & $\begin{array}{c}0.04 \\
(0.050)\end{array}$ \\
\hline$C U$ & $\begin{array}{c}0.49^{* * *} \\
(0.119)\end{array}$ & $\begin{array}{c}-0.1 \\
(0.096)\end{array}$ & $\begin{array}{l}0.59 * * * \\
(0.116)\end{array}$ & $\begin{array}{r}0.45^{* * *} \\
(0.112)\end{array}$ & $\begin{array}{c}-0.09 \\
(0.094)\end{array}$ & $\begin{array}{c}0.54 * * * \\
(0.118)\end{array}$ & $\begin{array}{l}0.46^{* * *} \\
(0.121)\end{array}$ & $\begin{array}{c}-0.08 \\
(0.103)\end{array}$ & $\begin{array}{l}0.54 * * * \\
(0.136)\end{array}$ \\
\hline Lag5 & & & & $\begin{array}{c}0.16^{*} \\
(0.080)\end{array}$ & $\begin{array}{c}-0.04 \\
(0.068)\end{array}$ & $\begin{array}{l}0.20^{* *} \\
(0.071)\end{array}$ & $\begin{array}{l}0.19^{* *} \\
(0.083)\end{array}$ & $\begin{array}{c}-0.03 \\
(0.082)\end{array}$ & $\begin{array}{l}0.22 * * \\
(0.077)\end{array}$ \\
\hline $\operatorname{Lag} 10$ & & & & & & & $\begin{array}{l}-0.08 \\
(0.071)\end{array}$ & $\begin{array}{c}-0.07 \\
(0.078)\end{array}$ & $\begin{array}{c}-0.02 \\
(0.077)\end{array}$ \\
\hline \multicolumn{10}{|l|}{ Total ATE } \\
\hline PTA & & & & & & & $\begin{array}{l}0.19^{* *} \\
(0.078)\end{array}$ & $\begin{array}{c}-0.20^{* *} \\
(0.091)\end{array}$ & $\begin{array}{l}0.40^{* * *} \\
(0.090)\end{array}$ \\
\hline FTA & & & & & & & $\begin{array}{l}0.35^{* *} \\
(0.132)\end{array}$ & $\begin{array}{c}-0.15 \\
(0.140)\end{array}$ & $\begin{array}{l}0.50^{* * *} \\
(0.124)\end{array}$ \\
\hline$C U$ & & & & & & & $\begin{array}{l}0.57^{* * *} \\
(0.188) \\
\end{array}$ & $\begin{array}{c}-0.17 \\
(0.154) \\
\end{array}$ & $\begin{array}{l}0.74 * * \\
(0.143) \\
\end{array}$ \\
\hline Observations & 182,314 & 182,314 & 182,314 & 162,976 & 162,976 & 162,976 & 134,031 & 134,031 & 134,031 \\
\hline
\end{tabular}

(Note) (i) Estimation using the log of trade (X), the log of the Intensive Margin (IM) or the log of the Extensive Margin (EM), respectively, as the dependent variable. PTA denotes Preferential Trade Agreement, FTA denotes Free Trade Agreement, CU denotes Customs Union and Common Market, Lag5 and Lag10 are the five and ten year lagged values of the respective variables, and ATE means the total Average Treatment Effect.

(ii) Estimation includes country-year and pair fixed effects. Standard errors clustered by country pair and year appear below the coefficient. $* * * p<0.01, * * p<0.05$, and $* p<0.1$. ATEs are computed using a two-tailed joint significance test.

We elaborate further on the margins of trade and differential timing of EIAs in the next section. 


\section{Differential timing of EIAs}

In column (2) and column (3) of Table 2, we added five and ten year lags to the specifications. Note that, when adding five and ten year lags, only agreements enforced by 2008 and 2003, respectively, are considered. We find that trade agreements continue having effects on trade flows up to five years after the EIA has entered into force. As mentioned earlier, this is because of two reasons. First, many stipulations of trade agreements only enter into force after a certain period of time, since EIAs are typically phased-in over a period of five to ten years. Second, it takes time for the terms of trade to adjust to a new paradigm.

In contrast to Baier, Bergstrand, and Feng (2014), we do not find any effect of EIAs for up to ten years. This suggests that the average onset of the effects of EIAs with a European partner is faster than the average EIA.

Taking a closer look, we see that PTAs do not have a contemporaneous effect on trade flows, but they do have a small positive effect $(+8 \%)$ in the medium term. FTAs increase total trade flows on average by $11 \%$ after five years, while CUs increase them on average by $21 \%$.

Looking at the margins, we find that these lagged effects are completely driven by changes in the relative number of goods traded. In contrast to Baier, Bergstrand, and Feng (2014), we do not find that the intensive margin effects of EIAs precede the extensive margin effects. Our findings also contradict the theoretical works of Ruhl (2008) and Arkolakis, Eaton and Kortum (2012), who argue that the effects on the extensive margin are delayed due to fixed export costs and delayed consumer responses, respectively. This again suggests that EU EIAs have very quick effects on trade flows.

In order to determine the cumulative effects of EIAs over time, we calculate the total average treatment effects (ATEs) using a two-tailed joint significance test. ${ }^{9}$ We find that PTAs have a small, but positive and statistically significant, effect on trade flows over time $(+21 \%)$, while FTAs and CUs have moderate $(+42 \%)$ and large effects $(+77 \%)$, respectively, in the long run.

${ }^{9}$ This is in contrast to Baier, Bergstrand, and Feng (2014) who simply take the sum of the coefficients that are statistically significant. 


\section{Effects of individual EIAs}

We now look at the different EU EIAs separately. How does each FTA and CU influence trade flows between the $27 \mathrm{EU}$ countries and the rest of the world?

For this analysis, we swap the FTA and CU dummies in Equation (3) for a separate dummy for each agreement. ${ }^{10}$ Our results are summarized in Figure 1. The full regression output can be found in Appendix 4. Consistent with our baseline results, we find that most trade agreements have a positive effect on total trade flows. A majority of EIAs in our sample (11 or $55 \%)$ increase contemporaneous trade flows, while eight $(40 \%)$ do not have any statistically significant effect and one; namely, the FTA with Albania, has decreased total trade flows.

This is in contrast to Kohl (2014), who finds that, of the 166 trade agreements in his sample, $64 \%$ has no statistically significant total treatment effect on trade flows, $27 \%$ has trade promoting effects and $10 \%$ has negative total treatment effects.

Looking at the margins, we find again that the extensive margins dominate. For most EIAs, we find that the increase in trade flows is driven by an expansion of the relative amount of goods traded and not by an increase in the value of goods traded. The only exceptions are Tunisia and Morocco, where we find positive effects on the intensive margin and a small negative effect on the extensive margin.

\footnotetext{
${ }^{10}$ Note that we cannot estimate the individual effects of the agreements with Papua New Guinea, CARIFORUM, Cameroon, Mauritius, Seychelles, Madagascar, Zimbabwe, Botswana, Lesotho, Swaziland, Mozambique, Montenegro, Bosnia and Herzegovina, Serbia, Switzerland, South Korea, Colombia, Peru, Honduras, Panama, Nicaragua, Costa Rica, and El Salvador because of collinearity. Most of these agreements have only entered into force in the last year(s) of our sample or were concluded with countries that have poor data availability. Therefore, we group them together as a control variable. This control variable also absorbs all other EIAs that are not captured by the separate agreement dummies (namely PTAs and EIAs that were in place between the rest of the world and the EU countries before they were part of the EU).
} 


\section{Figure 1. Contemporaneous effects of individual EIAs}

( $\%$ change in trade flows)

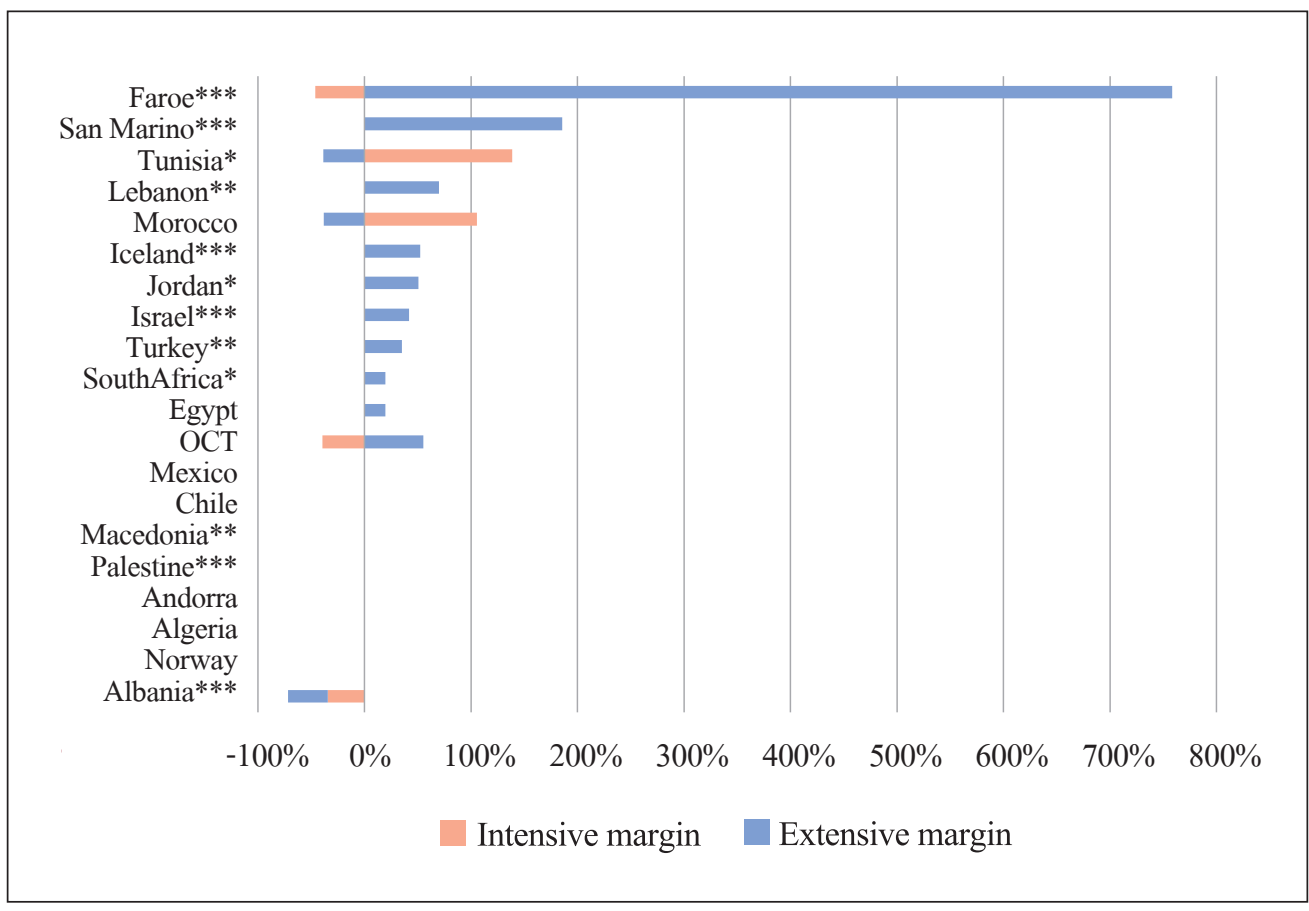

(Note)(i) Results are estimated using a GLS estimation with three sets of fixed effects. The full regression output can be found in Appendix 4.

(ii) Contracting parties of each agreement on the vertical axis. Horizontal axis reports the effects on the intensive and extensive margins.

(iii) The stars next to the agreements indicate statistical significance of the estimate for the total trade flow $(* * * p<0.01, * * p<0.05$, and $* p<0.1$ ). Only estimates for the margins that are statistically significant at the $10 \%$ threshold are shown in the graph. Note that computing total ATEs with five and ten year lags would mean that we could only look at EIAs enforced by 2003.

(Source) Authors' calculations.

\section{E. Motivation matters}

Since the start of the EU, EU trade policy has differentiated between different groups of countries by granting them different preferences.

The classification of the many different types of EU EIAs into only three categories is therefore rather crude. 
Persson and Wilhemsson (2007) ${ }^{11}$ use the notion of "pyramid of privilege" to study different European PTA schemes and the "privileges" or trade benefits they offer. We extend this framework to EIAs with a deeper level of integration and also include FTAs and CUs. Moreover, we not only look at the degree of market access offered by each EIA subtype, but also look at the motivation for concluding trade agreements, as the EU has many different motives for undertaking EIAs, some of which are more economically inspired, while others are more politically inspired (see Woolcocke 2007, for a discussion of the different EU motivations).

We distinguish between the following subtypes of EIAs (European Commission 2014).

The Generalised Scheme of Preferences (GSP) is a one-way PTA system allowing developing country exporters to pay lower or no duties on their exports to the EU. The goal is to contribute to their country's economic growth by granting access to EU markets. The Everything But Arms (EBA) arrangement is similar, but only for the least developed countries. It is more encompassing, as it grants duty- and quota-free access for all products, except arms and ammunition. Economic Partnership Agreements (EPAs) and Cooperation Agreements (CAs) are both TWPTAs, and they grant more or, at least, as many privileges as the GSP and EBA schemes.

Stabilisation and Association Agreements (SAAs) were made to establish a progressive partnership with the Western Balkan countries that aims to stabilize the region and establish a free trade area, eventually leading to EU membership. Hence, the motivation for these agreements is mainly political. Association Agreements (AAs) are agreements setting up an all-embracing framework to conduct bilateral relations, close political and economic cooperation, as well as human rights and democratic principles. FTAs are a core component of these objectives. "Free Trade Agreements" (EUFTAs) ${ }^{12}$ are economic EIAs that are created for the purpose of increasing market access and stimulating trade. Deep and Comprehensive FTAs (DCFTAs) or the so-called new generation FTAs are more ambitious than EUFTAs in lifting trade barriers. Finally, there are European Economic Area Agreements and Customs Unions (EUCUs), which are formed for economic, as well as political, reasons and they grant their beneficiaries very extensive market access.

Appendix 1 lists all agreements and their respective subtypes. Plotting these

\footnotetext{
${ }^{11}$ We thank an anonymous referee for this suggestion.

${ }^{12}$ In order to distinguish between what the EU calls "free trade agreements" and the more general class of FTAs, we henceforth call the former EUFTAs.
} 
agreements according to their market access and the EU motivations for adopting them results in Figure 2. Note that, unsurprisingly, there exists a strong and positive relationship between motivation and privilege.

In order to check if this distinction also affects the data, we rerun our baseline model, but now include a dummy for each of these agreements instead of the PTA, FTA, and CU dummies in Equation (3). We also include a control variable that absorbs all EIAs not captured by these dummies.

Note that most EPAs entered into force after 2009 and that there are only a small number of CAs. This is why we merge both of these subtypes into one category, called TWPTA. Moreover, the first DCFTA was concluded with South Korea and only entered into force in 2011. Hence, we collapse both EUFTAs and DCFTAs into one category.

Our results are outlined in Table 3. We find that the motivation for establishing EIAs matters. Looking at the contemporaneous effects, we find that GSP, EBA, TWPTAs, and SAAs do not have any effect on total trade flows, while AAs, EUFTAs, and EUCUs increase trade flows on average by $35 \%, 105 \%$, and $35 \%$, respectively. Thus, EIAs adopted for only economic reasons double trade flows, while EIAs adopted for both political and economic reasons also increase trade, but to a lesser extent. EIAs made for political reasons do not seem to have an impact on total trade flows.

This increase is entirely caused by an increase in the intensive margin for AAs, while for EUFTAs and EUCUs, it is completely driven by the extensive margin. Regarding GSP and EBA, we find positive effects on the extensive margin. This is completely offset by negative effects on the intensive margin, resulting in a zero effect on total trade flows. Thus, GSP and EBA result in increasing export diversification, but they do not manage to increase total revenues from trade. We find no effects on the margins for TWPTAs.

In terms of lags, we find positive effects up to ten years for GSP, as well as EBA, arrangements. This is driven by an increase in the extensive margin in the medium term. TWPTAs have no lagged effects.

For the AAs, EUFTAs, and EUCUs, we find positive and statistically significant effects up to five years. Again, this is driven by the extensive margin. For EUFTAs, we find small negative effects on total trade flows after ten year $(-21 \%)$, suggesting overshooting of the initial response to these trade agreements. 


\section{Figure 2. Classification of EU EIAs}

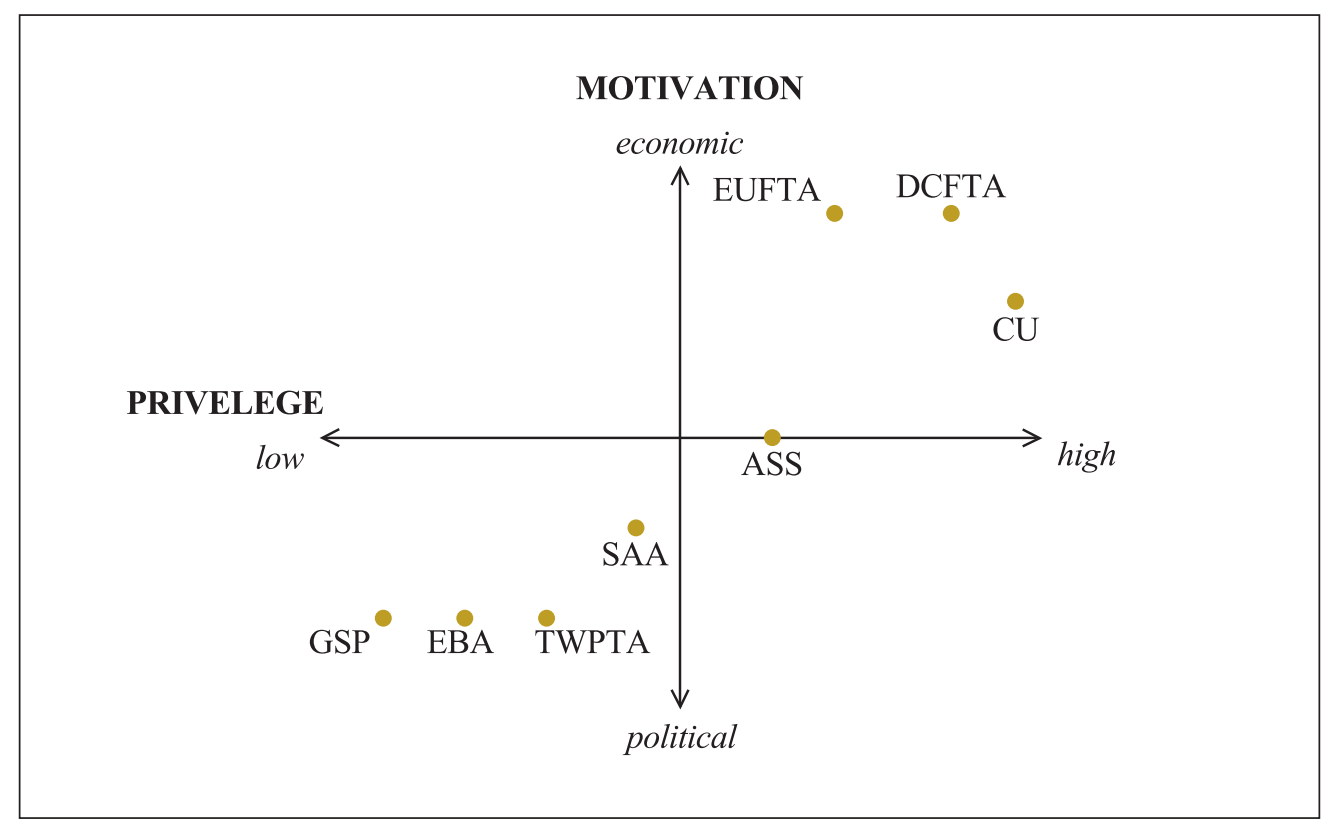

(Note) (i) EU EIAs are classified according to the degree of market access and motivation for concluding the EIAs.

(ii) GSP: Generalised Scheme of Preferences, EBA: Everything But Arms, TWPTA: Two-way Preferential Trade Agreement, SAA: Stabilisation and Association Agreement, ASS: Association Agreement, EUFTA: EU Free Trade Agreement, DCFTA: Deep and Comprehensive FTA, CU: Customs Union.

(Source) Authors' creation. 
Table 3. Impact of motivation and degree of privilege of EIAs

(GLS estimation using three sets of fixed effects)

\begin{tabular}{|c|c|c|c|c|c|c|c|c|c|}
\hline \multirow{2}{*}{$\begin{array}{l}\text { Independent } \\
\text { variables }\end{array}$} & \multicolumn{3}{|c|}{ Set (1) } & \multicolumn{3}{|c|}{ Set (2) } & \multicolumn{3}{|c|}{ Set (3) } \\
\hline & $\mathbf{X}$ & IM & EM & $\mathbf{X}$ & IM & EM & $\mathbf{X}$ & IM & EM \\
\hline GSP & $\begin{array}{c}0.05 \\
(0.052)\end{array}$ & $\begin{array}{l}-0.19^{* *} \\
(0.074)\end{array}$ & $\begin{array}{l}0.25^{* * * *} \\
(0.066)\end{array}$ & $\begin{array}{c}0.03 \\
(0.055)\end{array}$ & $\begin{array}{l}-0.20 * * \\
(0.075)\end{array}$ & $\begin{array}{l}0.23 * * * \\
(0.063)\end{array}$ & $\begin{array}{c}0.08 \\
(0.060)\end{array}$ & $\begin{array}{c}-0.10 \\
(0.073)\end{array}$ & $\begin{array}{l}0.18 * * \\
(0.064)\end{array}$ \\
\hline Lag5 & & & & $\begin{array}{l}0.12 * * \\
(0.048)\end{array}$ & $\begin{array}{c}-0.02 \\
(0.050)\end{array}$ & $\begin{array}{l}0.14 * * * \\
(0.032)\end{array}$ & $\begin{array}{l}0.12 * * \\
(0.046)\end{array}$ & $\begin{array}{c}-0.06 \\
(0.048)\end{array}$ & $\begin{array}{l}0.18^{* * *} \\
(0.036)\end{array}$ \\
\hline Lag10 & & & & & & & $\begin{array}{l}0.13 * * \\
(0.058)\end{array}$ & $\begin{array}{c}0.13^{*} \\
(0.067)\end{array}$ & $\begin{array}{c}0.00 \\
(0.053)\end{array}$ \\
\hline$E B A$ & {$\left[\begin{array}{c}-0.12 \\
(0.080)\end{array}\right.$} & $\begin{array}{l}-0.39^{* * *} \\
(0.130)\end{array}$ & $\begin{array}{l}0.27^{* *} \\
(0.101)\end{array}$ & $\begin{array}{c}-0.14 \\
(0.084)\end{array}$ & $\begin{array}{l}-0.38^{* *} \\
(0.133)\end{array}$ & $\begin{array}{l}0.24 * * \\
(0.093)\end{array}$ & $\begin{array}{c}-0.01 \\
(0.080)\end{array}$ & $\begin{array}{c}-0.27^{* *} \\
(0.122)\end{array}$ & $\begin{array}{l}0.26^{* *} \\
(0.115)\end{array}$ \\
\hline $\operatorname{Lag} 5$ & & & & $\begin{array}{c}0.13^{*} \\
(0.064)\end{array}$ & $\begin{array}{c}-0.1 \\
(0.077)\end{array}$ & $\begin{array}{l}0.23 * * * \\
(0.053)\end{array}$ & $\begin{array}{l}0.13 * * \\
(0.060)\end{array}$ & $\begin{array}{l}-0.13 \\
(0.08)\end{array}$ & $\begin{array}{l}0.26 * * * \\
(0.061)\end{array}$ \\
\hline $\operatorname{Lag} 10$ & & & & & & & $\begin{array}{l}0.24 * * \\
(0.087)\end{array}$ & $\begin{array}{c}0.13 \\
(0.084)\end{array}$ & $\begin{array}{c}0.11 \\
(0.074)\end{array}$ \\
\hline TWPTA & $\begin{array}{c}0.01 \\
(0.137)\end{array}$ & $\begin{array}{c}0.00 \\
(0.130)\end{array}$ & $\begin{array}{c}0.01 \\
(0.106)\end{array}$ & $\begin{array}{c}-0.05 \\
(0.131)\end{array}$ & $\begin{array}{c}-0.06 \\
(0.124)\end{array}$ & $\begin{array}{c}0.01 \\
(0.113)\end{array}$ & $\begin{array}{c}0.03 \\
(0.146)\end{array}$ & $\begin{array}{c}0.02 \\
(0.134)\end{array}$ & $\begin{array}{c}0.01 \\
(0.141)\end{array}$ \\
\hline $\operatorname{Lag} 5$ & & & & $\begin{array}{c}0.18 \\
(0.108)\end{array}$ & $\begin{array}{c}0.11 \\
(0.085)\end{array}$ & $\begin{array}{c}0.06 \\
(0.080)\end{array}$ & $\begin{array}{c}0.21 \\
(0.126)\end{array}$ & $\begin{array}{c}0.11 \\
(0.109)\end{array}$ & $\begin{array}{c}0.1 \\
(0.094)\end{array}$ \\
\hline $\operatorname{Lag} 10$ & & & & & & & $\begin{array}{c}0.04 \\
(0.088)\end{array}$ & $\begin{array}{c}0.04 \\
(0.097)\end{array}$ & $\begin{array}{c}0.00 \\
(0.084)\end{array}$ \\
\hline$S A A$ & $\begin{array}{c}-0.04 \\
(0.327)\end{array}$ & $\begin{array}{c}-0.31 \\
(0.327)\end{array}$ & $\begin{array}{l}0.27 * * * \\
(0.098)\end{array}$ & $\begin{array}{c}-0.10 \\
(0.332)\end{array}$ & $\begin{array}{c}-0.39 \\
(0.334)\end{array}$ & $\begin{array}{l}0.28^{* *} \\
(0.112)\end{array}$ & $\begin{array}{c}-0.08 \\
(0.324)\end{array}$ & $\begin{array}{c}-0.38 \\
(0.327)\end{array}$ & $\begin{array}{l}0.30^{* *} \\
(0.122)\end{array}$ \\
\hline Lag 5 & & & & $\begin{array}{c}-0.19 \\
(0.180)\end{array}$ & $\begin{array}{l}-0.36^{* *} \\
(0.147)\end{array}$ & $\begin{array}{c}0.17 \\
(0.114)\end{array}$ & $\begin{array}{c}-0.22 \\
(0.193)\end{array}$ & $\begin{array}{l}-0.40^{* *} \\
(0.159)\end{array}$ & $\begin{array}{c}0.18 \\
(0.109)\end{array}$ \\
\hline$A S S$ & {$\left[\begin{array}{l}0.30 * * * \\
(0.100)\end{array}\right.$} & $\begin{array}{l}0.32^{* * *} \\
(0.094)\end{array}$ & $\begin{array}{c}-0.02 \\
(0.071)\end{array}$ & $\begin{array}{l}0.32^{* * *} \\
(0.103)\end{array}$ & $\begin{array}{l}0.33^{* * * *} \\
(0.096)\end{array}$ & $\begin{array}{c}-0.01 \\
(0.076)\end{array}$ & $\begin{array}{l}0.27 * * \\
(0.120)\end{array}$ & $\begin{array}{l}0.22 * * \\
(0.092)\end{array}$ & $\begin{array}{c}0.05 \\
(0.073)\end{array}$ \\
\hline Lag5 & & & & $\begin{array}{l}0.18^{* *} \\
(0.078)\end{array}$ & $\begin{array}{c}0.02 \\
(0.079)\end{array}$ & $\begin{array}{l}0.16^{* * *} \\
(0.055)\end{array}$ & $\begin{array}{c}0.17^{*} \\
(0.091)\end{array}$ & $\begin{array}{c}-0.01 \\
(0.088)\end{array}$ & $\begin{array}{l}0.18^{* * *} \\
(0.061)\end{array}$ \\
\hline Lag10 & & & & & & & $\begin{array}{c}-0.01 \\
(0.112)\end{array}$ & $\begin{array}{c}-0.11 \\
(0.115)\end{array}$ & $\begin{array}{c}0.09 \\
(0.082)\end{array}$ \\
\hline EUFTA & $\begin{array}{l}0.72 * * * \\
(0.210)\end{array}$ & $\begin{array}{c}-0.29 \\
(0.193)\end{array}$ & $\begin{array}{l}1.01 * * * \\
(0.280)\end{array}$ & $\begin{array}{l}0.71^{* * *} \\
(0.204)\end{array}$ & $\begin{array}{c}-0.29 \\
(0.190)\end{array}$ & $\begin{array}{l}1.01 * * * \\
(0.262)\end{array}$ & $\begin{array}{l}0.73^{* * *} \\
(0.212)\end{array}$ & $\begin{array}{c}-0.13 \\
(0.145)\end{array}$ & $\begin{array}{l}0.87^{* * *} \\
(0.194)\end{array}$ \\
\hline $\operatorname{Lag} 5$ & & & & $\begin{array}{c}0.17^{*} \\
(0.090)\end{array}$ & $\begin{array}{l}-0.20 * * \\
(0.086)\end{array}$ & $\begin{array}{l}0.37 * * * \\
(0.111)\end{array}$ & $\begin{array}{l}0.24 * * \\
(0.102)\end{array}$ & $\begin{array}{c}-0.19 \\
(0.110)\end{array}$ & $\begin{array}{l}0.43 * * * \\
(0.129)\end{array}$ \\
\hline Lag10 & & & & & & & $\begin{array}{l}-0.23 * * \\
(0.094)\end{array}$ & $\begin{array}{c}-0.06 \\
(0.119)\end{array}$ & $\begin{array}{c}-0.17 \\
(0.131)\end{array}$ \\
\hline$E U C U$ & $\begin{array}{l}0.30 * * * \\
(0.101)\end{array}$ & $\begin{array}{c}-0.14 \\
(0.107)\end{array}$ & $\begin{array}{l}0.44 * * * \\
(0.118)\end{array}$ & $\begin{array}{l}0.24^{* *} \\
(0.101)\end{array}$ & $\begin{array}{c}-0.12 \\
(0.110)\end{array}$ & $\begin{array}{l}0.37 * * * \\
(0.126)\end{array}$ & $\begin{array}{l}0.28^{* *} \\
(0.125)\end{array}$ & $\begin{array}{c}-0.06 \\
(0.115)\end{array}$ & $\begin{array}{l}0.33^{* *} \\
(0.149)\end{array}$ \\
\hline Lag5 & & & & $\begin{array}{l}0.22 * * * \\
(0.072)\end{array}$ & $\begin{array}{c}-0.04 \\
(0.072)\end{array}$ & $\begin{array}{l}0.26 * * * \\
(0.077)\end{array}$ & $\begin{array}{l}0.22^{* *} \\
(0.078)\end{array}$ & $\begin{array}{c}-0.01 \\
(0.080)\end{array}$ & $\begin{array}{l}0.24 * * * \\
(0.079)\end{array}$ \\
\hline
\end{tabular}


(continued)

\begin{tabular}{|l|c|c|c|c|c|c|c|c|c|}
\hline \multirow{2}{*}{$\begin{array}{l}\text { Independent } \\
\text { variables }\end{array}$} & \multicolumn{3}{|c|}{ Set (1) } & \multicolumn{4}{c|}{ Set (2) } & \multicolumn{3}{c|}{ Set (3) } \\
\cline { 2 - 10 } & $\mathbf{X}$ & $\mathbf{I M}$ & $\mathbf{E M}$ & $\mathbf{X}$ & $\mathbf{I M}$ & $\mathbf{E M}$ & $\mathbf{X}$ & $\mathbf{I M}$ & $\mathbf{E M}$ \\
\hline \multirow{2}{*}{ Lag10 } & & & & & & & -0.12 & 0.05 & -0.17 \\
& & & & & & & $(0.118)$ & $(0.130)$ & $(0.148)$ \\
\hline \multirow{2}{*}{ Control } & 0.02 & $-0.15^{*}$ & $0.17 * *$ & 0.01 & $-0.15^{*}$ & $0.16^{* *}$ & 0.06 & -0.12 & $0.18^{* *}$ \\
& $(0.063)$ & $(0.080)$ & $(0.062)$ & $(0.062)$ & $(0.081)$ & $(0.066)$ & $(0.074)$ & $(0.094)$ & $(0.083)$ \\
\hline \multirow{2}{*}{ Lag5 } & & & & $0.07 *$ & -0.07 & $0.15^{* * *}$ & 0.06 & -0.06 & $0.13 * * *$ \\
& & & & $(0.042)$ & $(0.043)$ & $(0.034)$ & $(0.045)$ & $(0.049)$ & $(0.037)$ \\
\hline \multirow{2}{*}{ Lag10 } & & & & & & & $0.07 *$ & -0.03 & $0.10^{* *}$ \\
& & & & & & & $(0.037)$ & $(0.031)$ & $(0.038)$ \\
\hline Observations & 182,314 & 182,314 & 182,314 & 162,976 & 162,976 & 162,976 & 134,031 & 134,031 & 134,031 \\
\hline
\end{tabular}

(Note) ( i ) Estimation using the log of trade (X), the log of the Intensive Margin (IM) or the log of the Extensive Margin (EM), respectively, as the dependent variable. With GSP: Generalised Scheme of Preferences, EBA: Everything But Arms, TWPTA: Two-way Preferential Trade Agreement, SAA: Stabilisation and Association Agreement, ASS: Association Agreement, EUFTA: EU Free Trade Agreement, EUCU: EU Customs Union, and Lag5 and Lag10 denote the 5- and 10-year lagged value of the respective variable. Because most SAAs have only entered into force recently, lag 10 is omitted. Other captures all EIAs not captured by the GSP, EBA, TWPTA, SAA, ASS, EUFTA and EUCU dummies.

(ii) For a list of agreements per category, see Appendix 1. See text for a definition of each agreement category.

(iii) Estimation includes country-year and pair fixed effects. Standard errors clustered on country pair and year under the coefficient. $* * * p<0.01, * * p<0.05$, and $* p<0.1$.

\section{F. Effects of EIAs on individual countries}

Now we relax the assumption that trade agreements have a homogeneous impact on the countries that sign them and estimate the effects of PTAs, FTAs, and CUs on each EU27 country separately.

EIAs with EU countries are negotiated by the EU, but they will most likely not have a similar impact on all member states. The 27 economies of the EU differ considerably in terms of GDP, distance to extra-EU countries, sharing a common language with extra-EU countries, trade openness, ${ }^{13}$ and so on. EIAs can have very different economic effects, depending on the characteristics of the signatories (see, e.g., Vicard 2011 for a study showing empirically that the effectiveness of an EIA in enhancing bilateral

\footnotetext{
${ }^{13}$ Arribas, Pérez, and Tortosa-Ausina (2011), for example, show that there are very large differences in trade openness across the members of the EU, with Belgium, Luxembourg, Czech Republic, Hungary, the Netherlands, and Slovakia the most open countries, and Spain, the UK, and, especially, Greece the least open.
} 
trade flows depends on both the economic characteristics of the country pair and the characteristics of all other members of the EIA).

Results are presented in Figure 3. First of all, note that our results are consistent with the results from our baseline model. Deeper EIAs have larger effects on trade flows on average and the effects of PTAs, FTAs and CUs are mainly driven by the extensive margin.

Furthermore, we find that the effects of EIAs on trade are qualitatively similar for most countries: they experience a decrease in their intensive margin, while, at the same time, experiencing an increase in their extensive margin. The only exceptions are Cyprus and Romania. These two countries experience a statistically significant increase in their intensive margin due to CUs, which might be explained by their proximity to Turkey.

However, not all effects are statistically significant and there is great heterogeneity in the magnitude of the effects. For example, FTAs increase Ireland's extensive margin by nearly $150 \%$, but only $26 \%$ for Spain, and the EM effects for Poland are not statistically significant.

Moreover, while we find many statistically significant effects on the margins, the effects on total trade flows are less pronounced, with a majority of countries not experiencing any effects of PTAs and FTAs on trade flows. 
Figure 3. Contemporaneous effects of different types of EIAs

(\% change in trade flows)
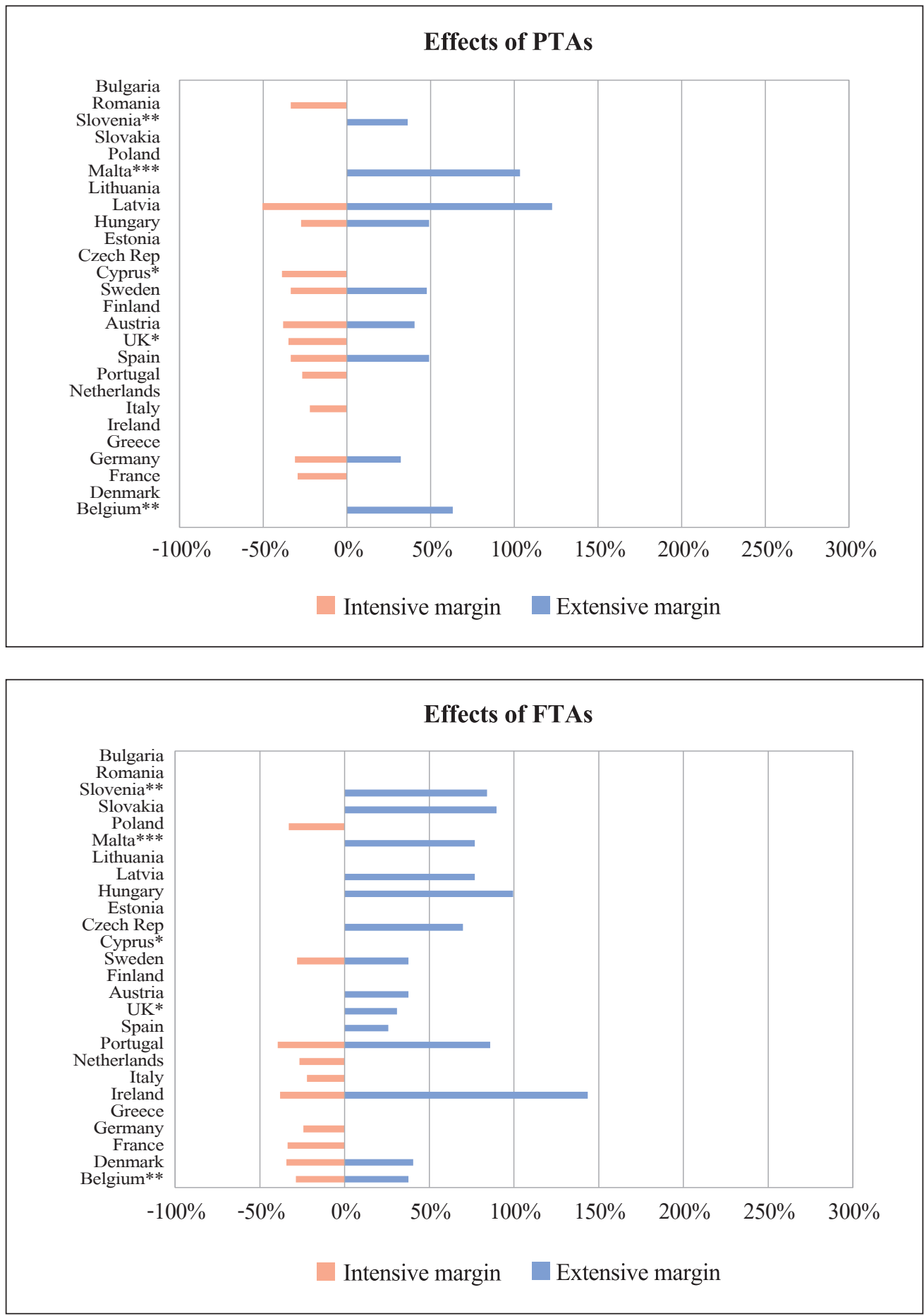


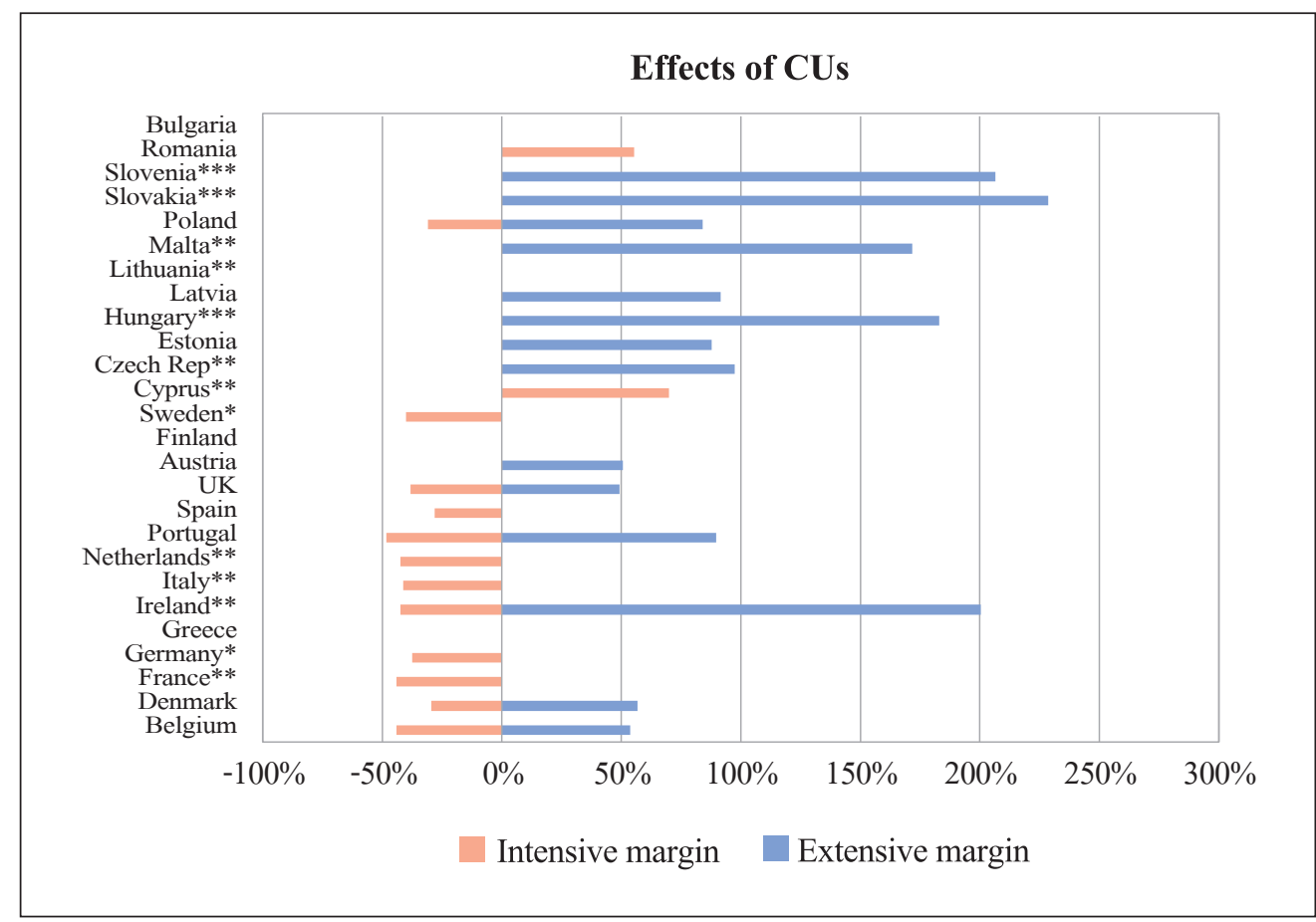

(Note) (i) Results are estimated using a GLS estimation with three sets of fixed effects. The full regression output can be retrieved upon request to the authors.

(ii) EU member states on the vertical axis. Horizontal axis reports the effects on the intensive and extensive margins.

(iii) The stars next to the agreements indicate statistical significance of the estimate for the total trade flow $(* * * p<0.01, * * p<0.05$, and $* p<0.1$ ). Only estimates for the margins that are statistically significant at the $10 \%$ threshold are shown in the graph.

(Source) Authors' calculation.

\section{G. Directionality of the effects}

Finally, we relax the assumption that EIAs have symmetric effects on imports and exports. As most EIAs have different stipulations for imports and exports, we expect to find different effects for extra-EU imports, extra-EU exports and intra-EU trade.

Results for the baseline model are presented in Table 4. Note that there are no intraEU PTAs and that PTAs mainly consist of TWPTAs for extra-EU exports, while both OPTAs and TWPTAs are present for extra-EU imports.

Consistent with the baseline model, we find that PTAs do not have any effect on total trade flows. Looking at the margins however, we now see that PTAs increase the 
intensive margin by $34 \%$ for exports, while PTAs increase the extensive margin by $30 \%$ for imports. PTAs also increase the extensive margin after five years for imports, but not for exports.

Second, and most surprisingly, the effect of FTAs on trade flows is completely driven by the effect of FTAs on imports. FTAs do not have an effect on extra-EU exports. Looking at the margins, we see that FTAs have a moderately positive effect on the extensive margin for extra-EU exports, while they have a big impact on imports. After five years, FTAs have a moderately positive impact on exports, but a small impact on imports. Hence, the accumulated impact of FTAs on the EM is similar for imports and exports, in which the impact on imports materializes faster than that for exports.

Finally, looking at the estimates for CU, we find large effects for both exports and imports. Extra-EU exports increase by $75 \%$. This is completely driven by the extensive margin. This strong effect continues up to five years after entry into force $(+33 \%)$. On the import-side, we find that the effect of CUs is almost identical to the effect of FTAs on extra-EU imports.

Results for each agreement separately are presented in Figure 4. We find that the majority of trade agreements does not have symmetric effects on imports and exports: for 12 agreements $(60 \%)$ we find a positive effect on imports, but no or a negative effect on exports, and vice versa. For the other eight agreements, we find that the effects have the same sign for both imports and exports, but the magnitude of the effects differs. Moreover, we find that EIAs have similar effects on imports and exports on average (i.e., a moderate increase), but this does not hold for each agreement separately.

Results for the different EU agreements are presented in Appendix 3. We find that the lack of any effect of the TWPTAs on total trade is caused by the opposing effects on imports and exports: TWPTAs decrease the intensive margin of EU imports, while increasing the intensive margin of EU exports. However, this contraction in trade values is only temporary and it is offset after five years by an expansion of the extensive margin of trade.

SAAs increase the number of products traded for both imports and exports. However, this is counteracted by a decrease in the value traded per good for imports, but not for exports, resulting in negative total trade flow effects for imports, but not for exports.

For AAs, we find symmetric effects for both imports and exports. 
Table 4. Directional effects of EIAs

(GLS estimation using three sets of fixed effects)

\begin{tabular}{|c|c|c|c|c|c|c|c|c|c|}
\hline \multirow{2}{*}{$\begin{array}{l}\text { Independent } \\
\text { variables }\end{array}$} & \multicolumn{3}{|c|}{ Set (1) } & \multicolumn{3}{|c|}{ Set (2) } & \multicolumn{3}{|c|}{ Set (3) } \\
\hline & $\mathbf{X}$ & IM & EM & $\mathbf{X}$ & IM & EM & $\mathbf{X}$ & IM & EM \\
\hline \multicolumn{10}{|c|}{ ExtraEU imports } \\
\hline PTA & $\begin{array}{c}0.03 \\
(0.060)\end{array}$ & $\begin{array}{l}-0.23 * * * \\
(0.076)\end{array}$ & $\begin{array}{l}0.26^{* * *} \\
(0.063)\end{array}$ & \begin{tabular}{c|c|}
0.02 \\
$(0.061)$
\end{tabular} & $\begin{array}{l}-0.22 * * * \\
(0.077)\end{array}$ & $\begin{array}{l}0.24 * * * \\
(0.066)\end{array}$ & $\begin{array}{c}0.08 \\
(0.065)\end{array}$ & $\begin{array}{l}-0.21 * * \\
(0.080)\end{array}$ & $\begin{array}{l}0.29 * * * \\
(0.075)\end{array}$ \\
\hline $\operatorname{Lag} 5$ & & & & $\begin{array}{c}0.08^{*} \\
(0.046)\end{array}$ & $\begin{array}{c}-0.05 \\
(0.049)\end{array}$ & $\begin{array}{l}0.14 * * * \\
(0.042)\end{array}$ & $\begin{array}{c}0.06 \\
0.051)\end{array}$ & $\begin{array}{c}-0.06 \\
(0.048)\end{array}$ & $\begin{array}{l}0.12 * * \\
(0.046)\end{array}$ \\
\hline Lag10 & & & & & & & $\begin{array}{c}0.07 \\
(0.051)\end{array}$ & $\begin{array}{c}0 \\
(0.054)\end{array}$ & $\begin{array}{c}0.07 \\
(0.046)\end{array}$ \\
\hline FTA & $\begin{array}{l}0.34^{* * *} \\
(0.087)\end{array}$ & $\begin{array}{c:c}-0.08 \\
(0.080)\end{array}$ & $\begin{array}{l}0.42 * * * \\
(0.075)\end{array}$ & $\begin{array}{l}0.32 * * * \\
(0.084)\end{array}$ & $\begin{array}{c}-0.08 \\
(0.084)\end{array}$ & $\begin{array}{l}0.40^{* * *} \\
(0.077)\end{array}$ & $\begin{array}{l}0.40^{* * *} \\
(0.111)\end{array}$ & $\begin{array}{c}-0.01 \\
(0.091)\end{array}$ & $\begin{array}{l}0.41 * * * \\
(0.099)\end{array}$ \\
\hline $\operatorname{Lag} 5$ & & & & $\begin{array}{c}0.12 \\
(0.074)\end{array}$ & \begin{tabular}{c|c}
-0.05 \\
$(0.061)$
\end{tabular} & $\begin{array}{l}0.17 * * \\
(0.060)\end{array}$ & $\begin{array}{c}0.10 \\
(0.082)\end{array}$ & $\begin{array}{c}-0.04 \\
(0.075)\end{array}$ & $\begin{array}{c}0.14 * \\
(0.071)\end{array}$ \\
\hline Lag10 & & & & & & & $\begin{array}{c}0.05 \\
(0.080)\end{array}$ & $\begin{array}{c}-0.02 \\
(0.069)\end{array}$ & $\begin{array}{c}0.07 \\
(0.074)\end{array}$ \\
\hline$C U$ & $\begin{array}{l}0.32 * * \\
(0.123)\end{array}$ & $\begin{array}{c:c}0.02 & \\
(0.105) & \end{array}$ & $\begin{array}{l}0.30^{* *} \\
(0.121)\end{array}$ & $\begin{array}{l:}0.32 * * \\
(0.125)\end{array}$ & $\begin{array}{c}0.04 \\
(0.104)\end{array}$ & $\begin{array}{l}0.28^{* *} \\
(0.121)\end{array}$ & $\begin{array}{l}0.30^{* *} \\
0.122)\end{array}$ & $\begin{array}{c}0.04 \\
(0.116)\end{array}$ & $\begin{array}{c}0.26^{*} \\
(0.135)\end{array}$ \\
\hline $\operatorname{Lag} 5$ & & & & \begin{tabular}{|c|c|}
0.03 \\
$(0.091)$
\end{tabular} & \begin{tabular}{c|c}
-0.13 & \\
$(0.089)$ &
\end{tabular} & $\begin{array}{l}0.16^{* *} \\
(0.073)\end{array}$ & $\begin{array}{c}0.02 \\
(0.099)\end{array}$ & $\begin{array}{c}-0.12 \\
(0.107)\end{array}$ & $\begin{array}{c}0.13 \\
(0.083)\end{array}$ \\
\hline $\operatorname{Lag} 10$ & & & & & & & \begin{tabular}{c}
-0.12 \\
$(0.096)$ \\
\hdashline
\end{tabular} & $\begin{array}{c}0.04 \\
(0.101)\end{array}$ & $\begin{array}{c}-0.16 \\
(0.111)\end{array}$ \\
\hline \multicolumn{10}{|c|}{ ExtraEU exports } \\
\hline PTA & $\begin{array}{c}0.10 \\
(0.124)\end{array}$ & $\begin{array}{l}0.29^{* * *} \\
(0.102)\end{array}$ & $\begin{array}{l}-0.19 * * \\
(0.089) \\
\end{array}$ & $\begin{array}{c:c}0.08 \\
(0.119)\end{array}$ & $\begin{array}{c}0.25^{* *} \\
(0.100)\end{array}$ & $\begin{array}{c}-0.17 \\
(0.101)\end{array}$ & \begin{tabular}{c}
0.15 \\
$0.126)$ \\
\hdashline
\end{tabular} & $\begin{array}{l}0.29 * * * \\
-0.096)\end{array}$ & $\begin{array}{c}-0.14 \\
(0.121)\end{array}$ \\
\hline $\operatorname{Lag} 5$ & & & & $\begin{array}{c}0.05 \\
(0.116)\end{array}$ & $\begin{array}{c}0.08 \\
(0.086)\end{array}$ & $\begin{array}{l}-0.04 \\
(0.090)\end{array}$ & \begin{tabular}{c}
0.07 \\
$(0.126)$ \\
\hdashline
\end{tabular} & $\begin{array}{c}0.08 \\
(0.104)\end{array}$ & $\begin{array}{c}-0.02 \\
(0.097)\end{array}$ \\
\hline $\operatorname{Lag} 10$ & & & & & & & \begin{tabular}{c}
0.04 \\
$0.115)$ \\
\hdashline
\end{tabular} & $\begin{array}{c}-0.03 \\
(0.132)\end{array}$ & $\begin{array}{c}0.07 \\
(0.111)\end{array}$ \\
\hline FTA & $\begin{array}{c}0.08 \\
(0.116)\end{array}$ & $\begin{array}{c}-0.17 \\
(0.117)\end{array}$ & \begin{tabular}{c}
$0.24 *$ \\
$(0.122)$ \\
\hdashline
\end{tabular} & $\begin{array}{c:c}0.08 \\
(0.112)\end{array}$ & $\begin{array}{c}-0.16 \\
(0.116)\end{array}$ & $\begin{array}{c}0.24^{*} \\
0.118)\end{array}$ & \begin{tabular}{c}
0.06 \\
$0.123)$ \\
\hdashline
\end{tabular} & $\begin{array}{c}-0.19 \\
(0.138)\end{array}$ & $\begin{array}{c}0.25^{*} \\
(0.136)\end{array}$ \\
\hline $\operatorname{Lag} 5$ & & & & \begin{tabular}{|c|c|}
0.11 \\
$(0.097)$
\end{tabular} & $\begin{array}{c}-0.14 \\
(0.088)\end{array}$ & $\begin{array}{l}0.25^{* *} \\
(0.092)\end{array}$ & $\begin{array}{c}0.15 \\
(0.105)\end{array}$ & $\begin{array}{c}-0.12 \\
(0.090)\end{array}$ & $\begin{array}{l}0.27 * * \\
(0.092)\end{array}$ \\
\hline Lag10 & & & & & & & $\begin{array}{c}-0.08 \\
(0.092)\end{array}$ & $\begin{array}{l}-0.20 * * \\
(0.090)\end{array}$ & $\begin{array}{c}0.12 \\
(0.096)\end{array}$ \\
\hline$C U$ & $\begin{array}{l}0.56^{* * *} \\
(0.163)\end{array}$ & $\begin{array}{c}-0.25 \\
(0.156)\end{array}$ & $\begin{array}{l}0.81^{* * *} \\
(0.177)\end{array}$ & $\begin{array}{l}0.49^{* * *} \\
(0.146)\end{array}$ & $\begin{array}{c}-0.25 \\
(0.154)\end{array}$ & $\begin{array}{l}0.75^{* * *} \\
(0.176)\end{array}$ & $\begin{array}{l}0.54^{* *} \\
(0.208) \\
\end{array}$ & $\begin{array}{c}-0.15 \\
(0.176)\end{array}$ & $\begin{array}{l}0.69^{* *} \\
(0.242)\end{array}$ \\
\hline $\operatorname{Lag} 5$ & & & & $\begin{array}{l}0.35^{* * *} \\
(0.112)\end{array}$ & $\begin{array}{c}0.06 \\
(0.112)\end{array}$ & $\begin{array}{l}0.29^{* *} \\
(0.118)\end{array}$ & $\begin{array}{l}0.33^{* *} \\
(0.121)\end{array}$ & $\begin{array}{c}0.07 \\
(0.118)\end{array}$ & $\begin{array}{l}0.27^{* *} \\
(0.120)\end{array}$ \\
\hline $\operatorname{Lag} 10$ & & & & & & & $\begin{array}{c}-0.04 \\
(0.159)\end{array}$ & $\begin{array}{c}0.03 \\
(0.165)\end{array}$ & $\begin{array}{c}-0.06 \\
(0.160)\end{array}$ \\
\hline
\end{tabular}


(continued)

\begin{tabular}{|c|c|c|c|c|c|c|c|c|c|}
\hline \multirow{2}{*}{$\begin{array}{l}\text { Independent } \\
\text { variables }\end{array}$} & \multicolumn{3}{|c|}{ Set (1) } & \multicolumn{3}{|c|}{ Set (2) } & \multicolumn{3}{|c|}{ Set (3) } \\
\hline & $\mathbf{X}$ & IM & EM & $\mathbf{X}$ & IM & EM & $\mathbf{X}$ & IM & EM \\
\hline \multicolumn{10}{|l|}{ IntraEU trade } \\
\hline FTA & $\begin{array}{c}0.14 \\
(0.092)\end{array}$ & $\begin{array}{c}-0.09 \\
(0.118)\end{array}$ & $\begin{array}{c}0.24^{*} \\
(0.117)\end{array}$ & $\begin{array}{c}0.14 \\
(0.093)\end{array}$ & $\begin{array}{c}-0.09 \\
(0.117)\end{array}$ & $\begin{array}{c}0.23^{*} \\
(0.115)\end{array}$ & $\begin{array}{c}0.20^{*} \\
(0.114)\end{array}$ & $\begin{array}{c}0.05 \\
(0.131)\end{array}$ & $\begin{array}{c}0.15 \\
(0.131)\end{array}$ \\
\hline Lag5 & & & & $\begin{array}{c}0.03 \\
(0.060)\end{array}$ & $\begin{array}{c}-0.08 \\
(0.081)\end{array}$ & $\begin{array}{c:}0.11^{*} \\
(0.062)\end{array}$ & $\begin{array}{c}0.03 \\
(0.056)\end{array}$ & $\begin{array}{c}-0.13 \\
(0.096)\end{array}$ & $\begin{array}{c}0.16^{*} \\
(0.084)\end{array}$ \\
\hline Lag10 & & & & & & & $\begin{array}{c}0.05 \\
(0.042)\end{array}$ & $\begin{array}{c}0.08 \\
(0.062)\end{array}$ & $\begin{array}{c}-0.04 \\
(0.053)\end{array}$ \\
\hline$C U$ & $\begin{array}{c}0.50 * * * \\
(0.135)\end{array}$ & $\begin{array}{c}-0.15 \\
(0.103)\end{array}$ & $\begin{array}{l}0.65^{* * *} \\
0.122)\end{array}$ & $\begin{array}{l}0.47 * * * \\
(0.127)\end{array}$ & $\begin{array}{c}-0.13 \\
(0.100)\end{array}$ & $\begin{array}{l}0.61 * * * \\
(0.124)\end{array}$ & $\begin{array}{r}0.46^{* * *} \\
(0.132)\end{array}$ & $\begin{array}{c}-0.13 \\
(0.112)\end{array}$ & $\begin{array}{l}0.60 * * * \\
(0.134)\end{array}$ \\
\hline Lag 5 & & & & $\begin{array}{c}0.14 \\
(0.088)\end{array}$ & $\begin{array}{c}-0.05 \\
(0.083)\end{array}$ & $\begin{array}{l}0.19 * * \\
(0.077)\end{array}$ & $\begin{array}{l}0.19^{* *} \\
(0.090)\end{array}$ & $\begin{array}{c}-0.03 \\
(0.097)\end{array}$ & $\begin{array}{l}0.23 * * \\
(0.084)\end{array}$ \\
\hline Lag10 & & & & & & & $\begin{array}{c}-0.12 \\
(0.072) \\
\end{array}$ & $\begin{array}{c}-0.14^{*} \\
(0.077) \\
\end{array}$ & $\begin{array}{c}0.02 \\
(0.076) \\
\end{array}$ \\
\hline Observations & 182,314 & 182,314 & 182,314 & 162,976 & 162,976 & 162,976 & 134,031 & 134,031 & 134,031 \\
\hline
\end{tabular}

(Note) (i) Estimation using the log of trade (X), the log of the Intensive Margin (IM) or the log of the Extensive Margin (EM), respectively, as the dependent variable. With PTA denoting Preferential Trade Agreement, FTA Free Trade Agreement, CU Customs Union and Common Market and Lag5 and Lag10 the 5- and 10-year lagged value of the respective variable.

(ii) Estimation includes country-year and pair fixed effects. Standard errors clustered on country pair and year under the coefficient. ${ }^{* *} p<0.01,{ }^{* *} p<0.05$, and $* p<0.1$. 


\section{Figure 4. Directional contemporaneous effects of individual EIAs}

( $\%$ change in trade flows)

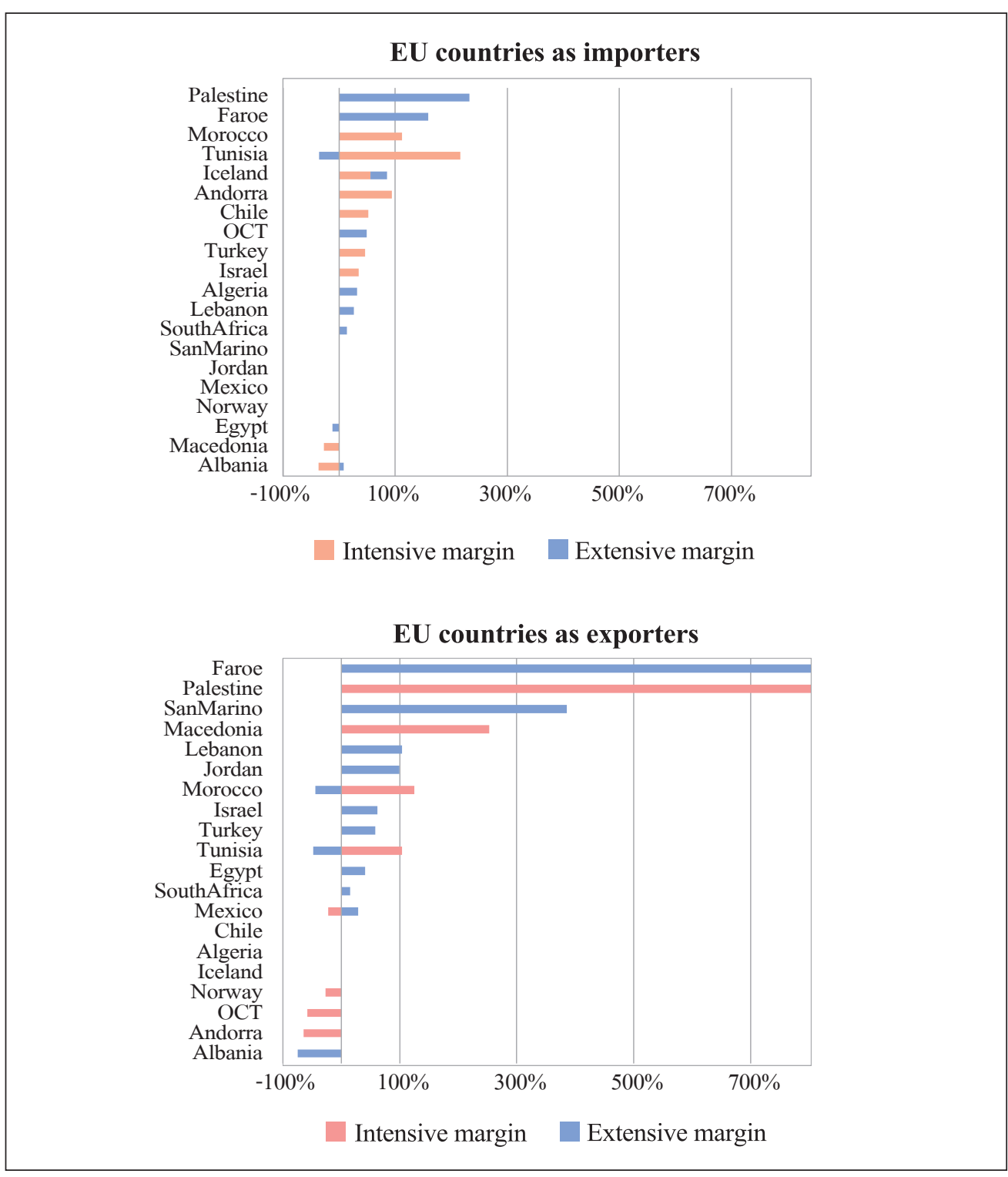

(Note) (i) Results are estimated using a GLS estimation with three sets of fixed effects. The full regression output can be retrieved upon request to the authors.

(ii) Contracting parties of each agreement on the vertical axis. Horizontal axis reports the effects on the intensive and extensive margins. Note that computing total ATEs with five and ten year lags would mean that we could only look at EIAs enforced by 2003.

(iii) The stars next to the agreements indicate statistical significance of the estimate for the total trade flow $(* * * p<0.01, * * p<0.05$, and $* p<0.1)$. Only estimates for the margins that are statistically significant at the $10 \%$ threshold are shown in the graph.

(Source) Authors' calculations. 
Furthermore, we find that EUFTAs have a large impact on EU imports (+63\%), but this is unimportant compared to their impact on exports $(+153 \%)$. This increase in trade continues up to five years after entry into force, while we find no lagged effects for imports. However, this effect is for exports again, partly offset after ten years, indicating overshooting of the initial response.

We find a similar pattern for EUCUs, which do not increase EU imports on average, but do increase exports by $54 \%$. This positive effect on exports becomes amplified after five years, but not for imports.

Results for the impact on the individual EU countries are presented in Figure 5.

In contrast to previous results, we now find negative effects on the extensive margin for PTAs and CUs for exports. We also find that FTAs and CUs have either no effect or positive effects on extra-EU imports. This is mainly driven by the extensive margin. On the export-side, we find mixed effects of FTAs and CUs: CUs have negative effects on the exports of EU15 countries (both Intensive margin and Extensive margin), but large positive effects on the exports of newer EU members (completely driven by Extensive margin, except for Hungary). 
Figure 5. Directional contemporaneous effects of different types of EIAs

(a) Effects of PTAs

( $\%$ change in trade flows)

\section{EU countries as importers}

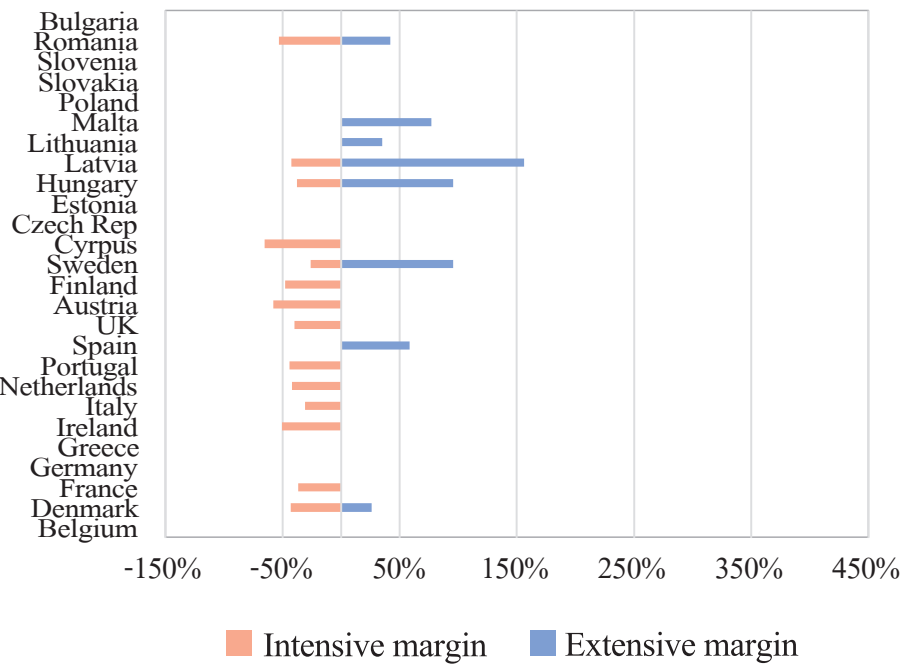

\section{EU countries as exporters}

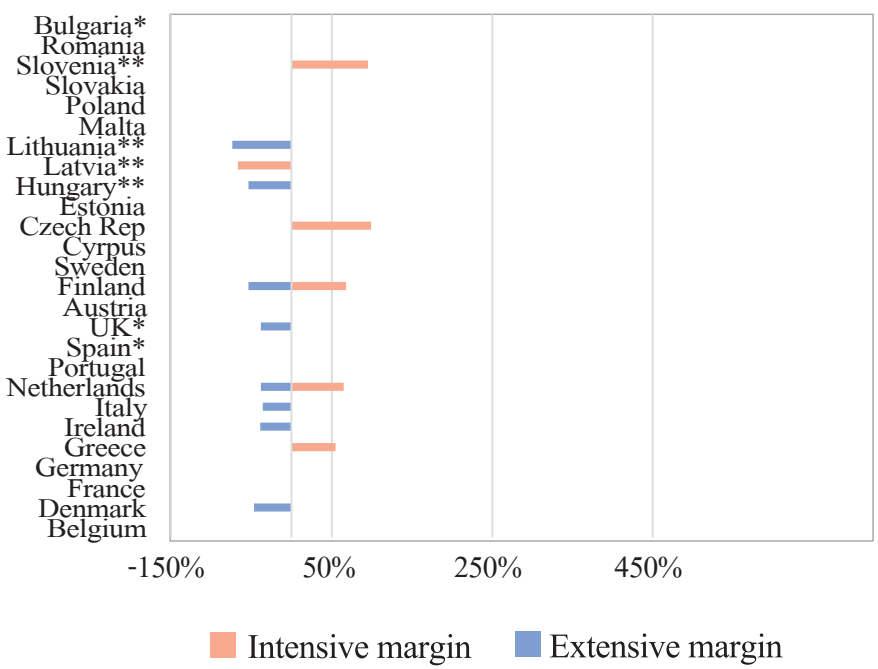




\section{EU countries as importers}

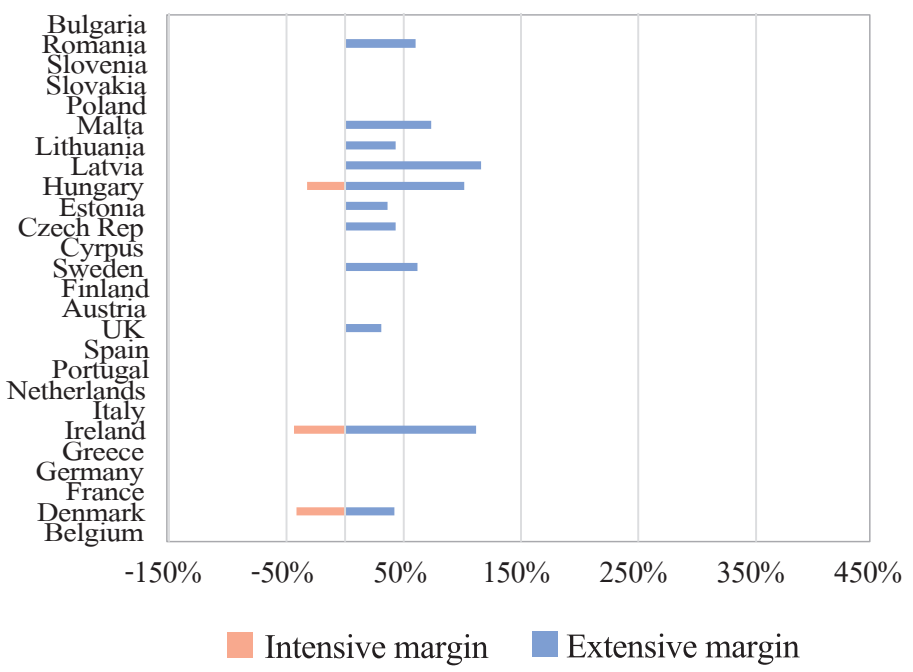

\section{EU countries as exporters}

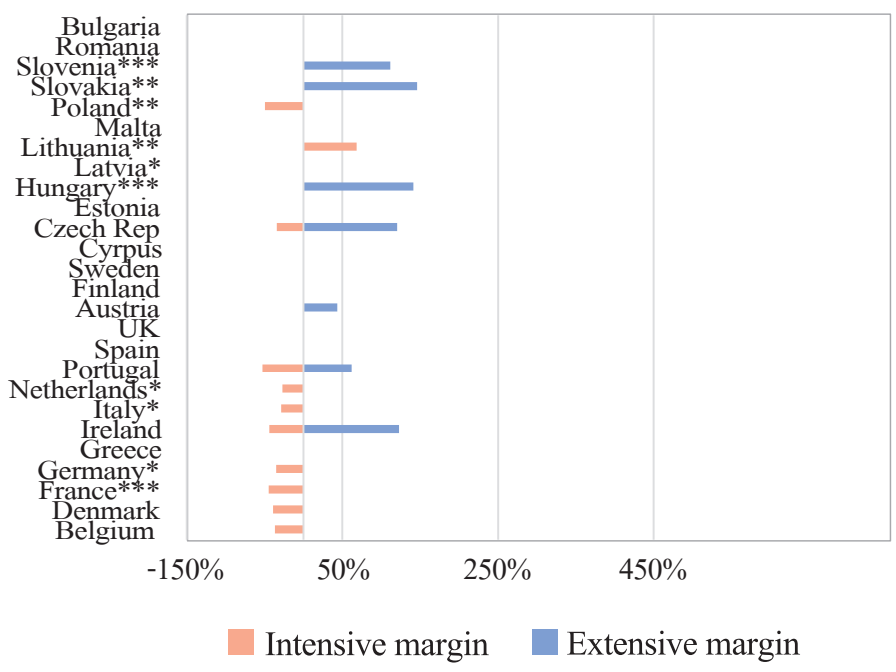




\section{EU countries as importers}

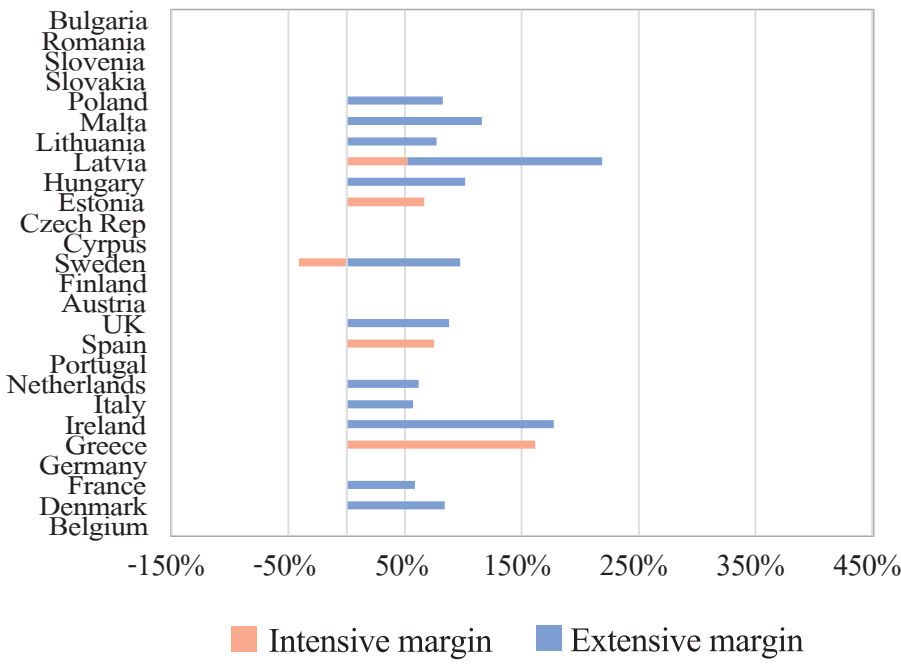

\section{EU countries as exporters}

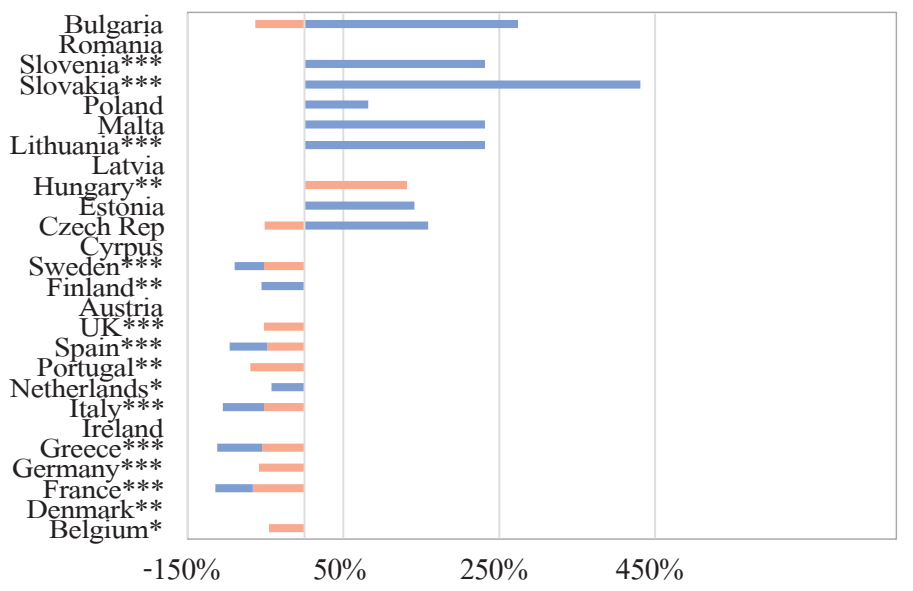

Intensive margin Extensive margin

(Note) (i) Results are estimated using a GLS estimation with three sets of fixed effects. The full regression output can be retrieved upon request to the authors.

(ii) EU member states on the vertical axis. Horizontal axis reports the effects on the intensive and extensive margins.

(iii) The stars next to the agreements indicate statistical significance of the estimate for the total trade flow $(* * p<0.01, * * p<0.05$, and $* p<0.1$ ). Only estimates for the margins that are statistically significant at the $10 \%$ threshold are shown in the graph.

(Source) Authors' calculations. 


\section{Robustness Checks}

\section{A. Strict exogeneity}

Generalized least squares (GLS) assumes strict exogeneity. If this assumption fails, the estimation will be biased. To test for strict exogeneity, Wooldridge (2010) suggests including leads of the EIA variables in levels in the fixed effects and differences estimations. If the EIA variables are endogenous, then the leads will be significant and the results for the fixed effects and differences specifications will be different, since a violation of the strict exogeneity assumption will bias both estimators in a different way.

Results for the exogeneity test are presented in Table 5. We computed the test with five-year leads, as well as with one-year leads. We find that all EIAs are strictly exogenous when using our fixed-effects specification. However, the assumption of strict exogeneity is violated for PTAs when using the differences specification.

In order to assess how much our results are biased due to these violations of the strict exogeneity assumption, and also as a robustness check, we compute our extended baseline model using differences. Taking the fourth difference ${ }^{14}$ of Equation (3) eliminates the country pair-fixed effects:

$$
\Delta_{4} \ln X_{i j t}=\beta_{0}+\beta_{1} \Delta_{4} P T A_{i j t}+\beta_{2} \Delta_{4} F T A_{i j t}+\beta_{3} \Delta_{4} C U_{i j t}+\Delta_{4} \delta_{i t}+\Delta_{4} \varphi_{j t}+\Delta_{4} \varepsilon_{i j t}
$$

where $\Delta_{4}$ represents the fourth difference.

Comparing the coefficients for the baseline model using the fixed-effects specification in Table 2 with the baseline model using the differences specification in Appendix 5, we find that the results are very similar. This similarity also holds for the PTA coefficient. This suggests that there is no endogeneity bias.

\footnotetext{
${ }^{14}$ Following Anderson and Yotov (2011), we use fourth differences instead of first differences, as trade flows typically change very slowly over time, making it very likely that first-differenced data will not display much variation. We obtain very similar results using fifth differences instead of fourth differences. As the latter makes us lose one year less of data, we choose to report our results using fourth differences. Results using fifth differences can be retrieved upon request.
} 


\section{Table 5. Exogeneity test}

(GLS estimation with fixed effects and differences)

\begin{tabular}{|c|c|c|c|c|}
\hline \multirow{2}{*}{$\begin{array}{l}\text { Independent } \\
\text { variables }\end{array}$} & \multicolumn{2}{|c|}{ Fixed effects } & \multicolumn{2}{|c|}{ Differences } \\
\hline & (1a) & (1b) & (2a) & (2b) \\
\hline PTA & 0.07 & 0.02 & & \\
\hline FTA & $0.23 * *$ & $0.13 *$ & & \\
\hline$C U$ & $0.46^{* * *}$ & $0.37 * * *$ & & \\
\hline$\Delta_{4} P T A$ & & & 0.04 & 0.02 \\
\hline$\Delta_{4} F T A$ & & & 0.09 & $0.05 * * *$ \\
\hline$\Delta_{4} C U$ & & & $0.30 * *$ & $0.27 * * *$ \\
\hline F.PTA & $\begin{array}{c}-0.06 \\
(0.038)\end{array}$ & & $\begin{array}{c}0.22 * \\
(0.121)\end{array}$ & \\
\hline F.FTA & $\begin{array}{c}-0.07 \\
(0.087)\end{array}$ & & $\begin{array}{c}0.11 \\
(0.145)\end{array}$ & \\
\hline$F . C U$ & $\begin{array}{c}0 \\
(0.091)\end{array}$ & & $\begin{array}{c}0.16 \\
(0.173)\end{array}$ & \\
\hline F5.PTA & & $\begin{array}{c}-0.18 \\
(0.122)\end{array}$ & & $\begin{array}{c}0.13 \\
(0.539)\end{array}$ \\
\hline F5.FTA & & $\begin{array}{c}-0.21 \\
(0.176)\end{array}$ & & $\begin{array}{c}0.14 \\
(0.617)\end{array}$ \\
\hline F5.CU & & $\begin{array}{c}-0.17 \\
(0.179)\end{array}$ & & $\begin{array}{c}0.23 \\
(0.515)\end{array}$ \\
\hline
\end{tabular}

(Note) (i) Estimation using the log of trade (column 1a and column 1b) and the differenced log of trade (column 2a and column 2 b), respectively, as the dependent variable. With PTA denoting Preferential Trade Agreement, FTA Free Trade Agreement, CU Customs Union and Common Market, $\Delta_{4}$ the fourth difference and F and F5 the 1-year and 5-year lead of the respective variables.

(ii) Estimations in column (1a) and column (1b) include country-year and pair fixed effects, while estimations in column (2a) and column (2b) use differenced data and include country-year fixed effects only. Standard errors clustered on country pair and year under the coefficient. $* * * p<0.01$, $* * p<0.05$, and $* p<0.1$.

\section{B. Changes over time of pair-specific unobservables}

Neither our fixed-effects specification nor differencing the data controls for changes over time in the pair-specific unobservables. This could, for example, be the case 
when fixed or variable export costs fall due to technological improvement. To partially alleviate this problem, Trefler (2004) and Baier, Bergstrand, and Feng (2014) use a random growth first-difference model. By including country pair-specific fixed effects in our difference model, we can account for changes in pair-specific unobservables that evolve smoothly over time.

This transforms our difference model in the following way:

$$
\Delta_{4} \ln X_{i j t}=\beta_{0}+\beta_{1} \Delta_{4} P T A_{i j t}+\beta_{2} \Delta_{4} F T A_{i j t}+\beta_{3} \Delta_{4} C U_{i j t}+\Delta_{4} \delta_{i t}+\Delta_{4} \varphi_{j t}+\rho_{i j}+\varepsilon_{i j t}
$$

Another option is to use our fixed-effects specification and include country pair-fixed effects interacted with a time trend. Our fixed-effects specification then becomes:

$$
\ln X_{i j t}=\beta_{0}+\beta_{1} P T A_{i j t}+\beta_{2} F T A_{i j t}+\beta_{3} C U_{i j t}+\delta_{i t}+\varphi_{j t}+\rho_{i j}+\rho_{i j} \cdot \mathrm{t}+\varepsilon_{i j t}
$$

where $t$ represents the time trend.

Results are presented in Appendix 6 and Appendix 7. First of all, note that the results for both the fixed-effects specification and the differences specification are very similar. This finding again strengthens our belief that the possible bias stemming from endogeneity of the EIA dummies is very small.

Second, we note that most estimates fail to reach statistical significance. FTAs and CUs no longer have a statistically significant contemporaneous impact on total trade flows. This is because standard errors are larger for most estimates, as well as because the magnitude of most coefficients is smaller. However, we do find positive and a statistically significant contemporaneous effect of PTAs and CUs on the extensive margin. This effect is partially offset by a negative effect after ten years for CUs.

\section{Conclusion}

This paper sheds new light on the impact of trade agreements on international trade patterns. It puts the traditional trade-creation effects of EIAs into a new perspective by pointing to various heterogeneous effects underpinning the general macro impact. New evidence is provided for the trade impact of EIAs negotiated by the EU with various 
trading partners in the period 1988 2013. Our findings have important implications for future trade policy, as well as for the international competitiveness of open economies.

First of all, we confirm the trade-creation effect of EIAs, but the size of the effect depends on the degree of integration implied by the agreement. FTAs and CUs clearly generate stronger cumulative trade effects than PTAs. Hence, effective trade integration requires deep integration. Moreover, the impact may follow the implementation of the agreement with a time lag. Hence, evaluating new agreements may lead to the wrong conclusion that trade is not affected. The actual impact may require some time to materialize.

A second striking finding is the crucial role of the extensive margin of trade. Trade is boosted by EIAs through increased product differentiation in exports and imports. This effect may also materialize later on, especially for exports under FTAs. Hence, EIAs open the door to trade in additional products rather than intensifying trade in previously exported products. Thus, on the one hand, companies can benefit from EIAs by launching new products for the destination markets covered by EU trade agreements. On the other hand, the value of traded products may decline.

Our results also indicate that the findings for one particular agreement or EU member state cannot be generalized for all agreements or EU member states. Although the impact across EU member states differs, EIAs positively affect the extensive margin and negatively affect the intensive margin for almost all trade by the EU member states. Hence, the positive role of the extensive margin can be confirmed at the level of the individual member states. Moreover, EIAs with a clear economic rationale appear to boost trade the most. Hence, EIAs signed for merely political reasons do not make much economic sense.

In sum, EIAs are an excellent tool to increase product differentiation and, through such differentiation, international trade. As many trading firms are confronted with significant barriers to entry into new markets or for new products, this specific effect of EIAs is very important in improving international competitiveness and boosting international trade.

Received 6 October 2016, Revised 11 January 2017, Accepted 24 January 2017 


\section{References}

Anderson, James E., and Yoto V. Yotov. "Terms of Trade and Global Efficiency of Free Trade Agreements.” NBER Working Paper no 17003 (2011).

Anderson, James E., and Eric Van Wincoop. "Gravity with Gravitas: A Solution to the Border Puzzle." American Economic Review. 93 (1) (2003): 170-192.

Arkolakis, Costas, Arnaud Costinot, and Andrés Rodriguez-Clare. "New Trade Models, Same Old Gains." American Economic Review, 102 (1) (2012): 94-130.

Arkolakis, Costas, Jonathan Eaton, and Samuel Kortum. "Staggered Adjustment and Trade Dynamics.” Yale University, mimeo (2012).

Fernández, Iván Arribas, Francisco Pérez García, and Emili Tortosa Ausina. "Trade Integration in the European Union; relative contributions of openness and interconnectedness." Paper presented at CESifo Economic Studies Conference on Measuring Economic Integration, Munich, Germany, February 18-19, 2011.

Baier, Scott L., and Jeffrey H. Bergstrand. "On the endogeneity of international trade flows and free trade agreements. Unpublished manuscript. http://www.nd.edu/ jbergstr/ Working_Papers/EndogeneityAug2002.pdf.

Baier, Scott L., and Jeffrey H. Bergstrand. "Economic determinants of free trade agreements.” Journal of International Economics, 64 (1) (2004): 29-63.

Baier, Scott L., Jeffrey H. Bergstrand, Peter Egger, and Patrick A. McLaughlin. "Do economic integration agreements actually work? Issues in understanding the causes and consequences of the growth of regionalism." The World Economy, 31 (4) (2008): 461497.

Baier, Scott L., and Jeffrey H. Bergstrand. "Do Free Trade Agreements actually Increase Members' international Trade?" Journal of International Economics, 71 (1) (2007): 7295.

Baier, Scott L., and Jeffrey H. Bergstrand, and Michael Feng. "Economic integration agreements and the margins of international trade." Journal of International Economics, 93 (2) (2014): 339-350.

Balassa, Bela. Economic Integration. In The New Palgrave Dictionary of Economics 
(London: Macmillan Press Reference Books, 1987).

Baldwin, Richard E. “The euro's trade effects.” ECB working paper series, no 594 (2006).

Bensassi, Sami, Laura Márquez-Ramos, and Inmaculada Martínez-Zarzoso. "Economic integration and the two margins of trade: the impact of the Barcelona Process on North African countries' exports." Journal of African economies, 21 (2) (2012): 228-265.

Bussière, Matthieu, Jarko Fidrmuc, and Bernd Schnatz. "EU enlargement and trade integration: Lessons from a gravity model." Review of Development Economics, 12 (3) (2008): 562-576.

Camarero, Mariam, Estrella Gómez, and Cecilio Tamarit. "EMU and intra-European trade. Long-run evidence using gravity equations." ThE working paper No. 10/25 (2012).

Cipollina, Maria, and Luca Salvatici. "Reciprocal Trade Agreements in Gravity Models: A Meta-Analysis.” Review of International Economics, 18(1) (2010): 63-80.

Council Regulation 3782/87/EEC applying generalized tariff preferences for 1988 to textile products originating in developing countries (1987) OJ L367.

Council Regulation 4259/88/EEC applying generalized tariff preferences for 1989 to textile products originating in developing countries (1988) OJ L375.

Council Regulation 3281/94/EC applying a four-year scheme of generalized tariff preferences (1995 to 1998) in respect of certain industrial products originating in developing countries (1994) OJ L348.

Council Regulation 2820/98/EC applying a multiannual scheme of generalised tariff preferences for the period 1 July 1999 to 31 December 2001 (1998) OJ L357.

Council Regulation 2501/2001/EC applying a scheme of generalised tariff preferences for the period from 1 January 2002 to 31 December 2004 (2001) OJ L346.

Council Regulation 980/2005/EC applying a scheme of generalised tariff preferences (2005) OJ L169.

Council Regulation 732/2008/EC applying a scheme of generalised tariff preferences (2008) OJ L211.

Council Regulation 978/2012/EU applying a scheme of generalised tariff preferences (2012) OJ L303. 
Dür, Andreas, Leonardo Baccini, and Manfred Elsig. "The Design of International Trade Agreements: Introducing a New Database." Review of International Organizations, 9(3) (2014): 353-375.

EFTA. "The European Free Trade Area." http://www.efta.int/about-efta/history. Retrieved August 2014.

European Commission. "Agreements.” http://ec.europa.eu/trade/policy/countries-andregions/agreements/. Retrieved August 2014.

Feenstra, Robert C. Advanced International Trade: Theory and Evidence. Princeton: Princeton University Press (2004).

Feenstra, Robert C., James R. Markusen, and Andrew K. Rose. "Using the gravity model equation to differentiate among alternative theories of trade." Canadian Journal of Economics, 34(2) (2001): 430-447.

Florensa, Luis Marcelo, Laura Márquez-Ramos, María Luisa Recalde. "The effect of economic integration and institutional quality of trade agreements on trade margins: evidence for Latin America." Review of World Economics, 151(2) (2015): 329-351.

Frankel, Jeffrey A. Regional Trading Blocs. Washington, DC: Institute for International Economics (1997).

Frankel, Jeffrey A., and Andrew K. Rose. "An estimate of the effect of common currencies on trade and income." The Quarterly Journal of Economics, 117 (2002): 437466.

Geldi, Hatice Kerra. "Trade effects of regional integration: A panel cointegration analysis." Economic Modelling, 29(5) (2012): 1566-1570.

Guimaraes, Paulo, and Pedro Portugal. "A Simple Feasible Alternative Procedure to Estimate Models with High-Dimensional Fixed Effects." Stata Journal, 10(4) (2010): 628-649.

Herderschee, Johannes, and Zhaogang Qiao. "Impact on Intra-European Trade Agreements, 1990-2005: Policy Implications for the Western Balkans and Ukraine." IMF Working Papers (2007): 1-43.

Hummels, David, and Peter J. Klenow. "The variety and quality of a nation's exports." The American Economic Review, 95(3) (2005): 704-723. 
Kelejian, Harry, George S. Tavlas, and Pavlos Petroulas. "In the neighborhood: The trade effects of the Euro in a spatial framework." Regional Science and Urban Economics, 42(1) (2012): 314-322.

Kohl, Tristan. "Do we really know that trade agreements increase trade?" Review of World Economics, 150(3) (2014): 443-469.

Kohl, Tristan, Steven Brakman, and Harry Garretsen. "Do Trade Agreements Stimulate International Trade Differently? Evidence from 296 Trade Agreements." The World Economy, 39 (2016): 97-131.

Lakatos, Csilla, and Lars Nilsson. "The EU-Korea FTA: anticipation, trade policy uncertainty and impact." Review of World Economics, (2016): 1-20.

Limão, Nuno. "Preferential trade agreements." National Bureau of Economic Research, working paper no 22138 (2016).

Magee, Christopher S. "Endogenous preferential trade agreements: An empirical analysis." Contributions in Economic Analysis and Policy, 2(1) (2003).

Magee, Christopher S. "New measures of trade creation and trade diversion." Journal of International Economics, 75(2) (2008): 349-362.

Manchin, Miriam. "Preference utilisation and tariff reduction in EU imports from ACP countries." The World Economy, 29(9) (2006): 1243-1266.

Márquez-Ramos, Laura, Luis Marcelo Florensa, and María Luisa Recalde. "Economic Integration Effects on Trade Margins: Sectoral Evidence from Latin America." Journal of Economic Integration, 30(2) (2015): 269-299.

McGill. "PTA database.” http://ptas.mcgill.ca. Retrieved August 2014.

Micco, Alejandro, Ernesto Stein, and Guillermo Ordoñez. "The currency union effect on trade: early evidence from EMU.” Economic policy, 18(37) (2003): 315-356.

Persson, Maria, and Fredrik Wilhelmsson. Assessing the effects of EU trade preferences for developing countries. The European Union and Developing Countries: Trade, Aid and Growth in an Integrating World. Cheltenham and Northampton: Edward Elgar, (2007): 29-48.

Rose, Andrew. K. "One money, one market? The effects of common currencies on international trade." Economic Policy, 15 (2000): 7-46. 
Roy, Jayit. "On the robustness of the trade-inducing effects of trade agreements and currency unions." Appalachian State University, mimeo (2012).

Ruhl, Kim J. “The international elasticity puzzle.” NYU, mimeo (2008).

Santos Silva, S. J. M. C. and Silvana Tenreyro. "The Log of Gravity." The Review of Economics and Statistics, 88(4) (2006): 641-658.

Spies, Julia, and Helena Marques. "Trade effects of the Europe agreements: A theory-based gravity approach." The Journal of International Trade and Economic Development, 18(1) (2009): 11-35.

Tinbergen, Jan. Shaping the world economy, New York, NY: Twentieth Century Fund (1962).

Trefler, Daniel. "Trade liberalization and the theory of endogenous protection: an econometric study of US import policy." Journal of Political Economy, 101(1) (1993):138-160.

Trefler, Daniel. "The long and short of the Canada-US free trade agreement." The American Economic Review 94(4) (2004): 870-895.

Tuck. "Tuck Trade Agreements Database." http://wits.worldbank.org/gptad/trade database.html. Retrieved August 2014.

Vicard, Vincent. "Determinants of successful regional trade agreements." Economics Letters, 111(3) (2011): 188-190.

Woolcock, Stephen. "European Union policy towards Free Trade Agreements." ECIPE Working Paper no 03/2007 (2007).

Wooldridge, Jeffrey M. Econometric analysis of cross section and panel data. Cambridge, MA: MIT Press (2010).

WorldTradeLaw.net. "FTA database.” http://www.worldtradelaw.net/fta/ftadatabase/ ftas.asp. Retrieved March 2013.

WTO. "Regional trade agreements information system.” http://rtais.wto.org. Retrieved August 2014. 


\section{Appendix 1: EIAs in force between the EU and the rest of the world}

\begin{tabular}{|c|c|c|c|c|c|c|c|}
\hline Date & Agreement & EIA & Type & Date & Agreement & EIA & Type \\
\hline 1964 & EU-Turkey & PTA & TWPTA & 2004 & EU-Egypt & FTA & ASS \\
\hline 1971 & EU-OCT & FTA & other & 2004 & EU-Montenegro & FTA & SAA \\
\hline 1973 & EU-Liechtenstein & FTA & EUFTA & 2005 & EU-Algeria & FTA & ASS \\
\hline 1973 & EU-Switzerland & FTA & EUFTA & 2006 & EU-Albania & FTA & SAA \\
\hline 1973 & EU-Iceland & FTA & EUFTA & 2008 & EU-Bosnia-Herzegovina & FTA & SAA \\
\hline 1973 & EU-Norway & FTA & EUFTA & 2009 & EU-Swaziland & PFTA & TWPTA \\
\hline 1978 & EU-Algeria & PTA & TWPTA & 2009 & EU-CARIFORUM & PTA & TWPTA \\
\hline 1978 & EU-Egypt & PTA & TWPTA & 2009 & EU-Mozambique & PTA & TWPTA \\
\hline 1991 & EU-Andorra & $\mathrm{CU}$ & EUCU & 2009 & EU-Namibia & PTA & TWPTA \\
\hline 1992 & EU-Albania & PTA & TWPTA & 2009 & EU-Madagascar & PTA & TWPTA \\
\hline 1994 & EU-Liechtenstein & $\mathrm{CM}$ & EUCU & 2009 & EU-Lesotho & PTA & TWPTA \\
\hline 1994 & EU-Iceland & $\mathrm{CM}$ & EUCU & 2009 & EU-Botswana & PTA & TWPTA \\
\hline 1994 & EU-Norway & $\mathrm{CM}$ & EUCU & 2009 & EU-Cameroon & PTA & TWPTA \\
\hline 1995 & EU-Israel & FTA & ASS & 2009 & EU-Zimbabwe & PTA & TWPTA \\
\hline 1996 & EU-Turkey & $\mathrm{CU}$ & EUCU & 2009 & EU-Mauritius & PTA & TWPTA \\
\hline 1997 & EU-Faeroe Islands & FTA & EUFTA & 2009 & EU-Seychelles & PTA & TWPTA \\
\hline 1997 & EU-Palestine & FTA & ASS & 2010 & EU-Serbia & FTA & SAA \\
\hline 1998 & EU-Tunisia & FTA & ASS & 2011 & EU-Papua New Guinea & PTA & TWPTA \\
\hline 2000 & EU-South Africa & FTA & other & 2011 & EU-South Korea & FTA & EUFTA \\
\hline 2000 & EU-Morocco & FTA & ASS & 2012 & EU-Iraq & PTA & TWPTA \\
\hline 2000 & EU-Mexico & FTA & EUFTA & 2013 & EU-Nicaragua & FTA & ASS \\
\hline 2001 & EU-Macedonia & FTA & SAA & 2013 & EU-Honduras & FTA & ASS \\
\hline 2002 & EU-Jordan & FTA & ASS & 2013 & EU-Peru & FTA & EUFTA \\
\hline 2002 & EU-San Marino & $\mathrm{CU}$ & EUCU & 2013 & EU-Panama & FTA & ASS \\
\hline 2003 & EU-Lebanon & FTA & ASS & 2013 & EU-Colombia & FTA & EUFTA \\
\hline 2003 & EU-Chile & FTA & EUFTA & & & & \\
\hline
\end{tabular}

(Note) (i) The table includes agreements for the period 1988 2013. Date refers to the (provisional) entry into force of an agreement.

(ii) With PTA denoting Preferential Trade Agreement, TWPTA: Two-way PTA, FTA: Free Trade Agreement, CU: Customs Union and Common Market, ASS: Association Agreement, SAA: Stabilisation and Association Agreement, EUFTA: EU FTA and EUCU: EU CU.

(iii) Generalised Scheme of Preferences, GSP+ and Everything But Arms have been omitted from the list due to space constraints. These schemes contains OPTAs with virtually all developing countries since the 1970s. EIAs with European countries before they were part of the EU have also been omitted from this list due to space constraints. 


\section{Appendix 2: List of countries in the dataset}

\begin{tabular}{|c|c|c|c|c|c|}
\hline Afghanistan & Albania & Algeria & Am. Samoa & Andorra & Angola \\
\hline Anguilla & Antarctica & Antigua & Barbuda & Argentina & Armenia \\
\hline Aruba & Australia & Austria & Azerbaijan & Bahamas & Bahrain \\
\hline Bangladesh & Barbados & Belarus & Belgium & Belize & Benin \\
\hline Bermuda & Bhutan & Bolivia & Bosnia Herz. & Botswana & Bouvet Isl. \\
\hline Brazil & British Indian OT & Virgin Isl. & Brunei Darussalam & Burkina Faso & Burundi \\
\hline Cabo Verde & Cambodia & Cameroon & Canada & Cayman Isl. & CAR \\
\hline Chad & Chile & China & Christmas Isl. & Cocos Isl. & Colombia \\
\hline Comoros & Congo & Cook Isl. & Costa Rica & Côte d'Ivoire & Cuba \\
\hline Czech Rep. & Denmark & Djibouti & Dominica & Dominican Rep. & DR Congo \\
\hline Ecuador & Egypt & El Salvador & Eq. Guinea & Eritrea & Estonia \\
\hline Ethiopia & Falkland Isl. & Faroe Isl. & Fiji & Finland & France \\
\hline Fr. Polynesia & French ST & Gabon & Gambia & Georgia & Germany \\
\hline Ghana & Greece & Greenland & Grenada & Guam & Guatemala \\
\hline Guinea & Guinea-Bissau & Guyana & Haiti & $\begin{array}{l}\text { Heard \& } \\
\text { McDonald Isl. }\end{array}$ & $\begin{array}{l}\begin{array}{l}\text { Holy See } \\
\text { (Vatican) }\end{array} \\
\end{array}$ \\
\hline Honduras & Hong Kong & Hungary & Iceland & India & Indonesia \\
\hline Iran & Iraq & Ireland & Israel & Italy & Jamaica \\
\hline Japan & Jordan & Kazakhstan & Kenya & Kiribati & Korea \\
\hline Kuwait & Kyrgyzstan & Laos & Latvia & Lebanon & Lesotho \\
\hline Liberia & Libya & Lithuania & Macao & Macedonia & Madagascar \\
\hline Malawi & Malaysia & Maldives & Mali & Malta & Marshall Isl. \\
\hline Mauritania & Mauritius & Mexico & Micronesia & Moldova & Mongolia \\
\hline Montenegro & Montserrat & Morocco & Mozambique & Myanmar & Namibia \\
\hline Nauru & Nepal & Neth. Antilles & Netherlands & New Caledonia & New Zealand \\
\hline Nicaragua & Niger & Nigeria & Niue & Norfolk Isl. & N Mariana Isl. \\
\hline North Korea & Norway & Oman & Pakistan & Palau & Palestine \\
\hline Panama & Papua New Guinea & Paraguay & Peru & Philippines & Pitcairn \\
\hline Poland & Portugal & Qatar & Romania & Russia & Rwanda \\
\hline Samoa & San Marino & $\begin{array}{l}\text { Sao Tome \& } \\
\text { Principe }\end{array}$ & Saudi Arabia & Senegal & Serbia \\
\hline Seychelles & Sierra Leone & Singapore & Slovakia & Slovenia & Solomon Isl. \\
\hline Somalia & $\begin{array}{l}\text { S Georgia \& } \\
\text { Sandwich Isl. }\end{array}$ & South Africa & Spain & Sri Lanka & St. Helena \\
\hline $\begin{array}{l}\text { Ascension \& } \\
\text { Tristan }\end{array}$ & St. Kitts \& Nevis & St. Lucia & $\begin{array}{l}\text { St. Pierre \& } \\
\text { Miquelon }\end{array}$ & $\begin{array}{l}\text { St. Vincent \& } \\
\text { Grenadines }\end{array}$ & Sudan \\
\hline Suriname & Swaziland & Sweden & Switzerland & Syria & Taiwan \\
\hline
\end{tabular}


(continued)

\begin{tabular}{|l|l|l|l|l|l|}
\hline Tajikistan & Tanzania & Thailand & Timor-Leste & Togo & Tokelau \\
\hline Tonga & Trinidad \& Tobago & Tunisia & Turkey & Turkmenistan & $\begin{array}{l}\text { Turks \& Caicos } \\
\text { Isl. }\end{array}$ \\
\hline Tuvalu & UAE & Uganda & UK & Ukraine & US Minor OI \\
\hline Uruguay & Virgin Isl. & USA & Uzbekistan & Vanuatu & Venezuela \\
\hline Vietnam & Wallis \& Futuna & Yemen & Zimbabwe & Zambia & \\
\hline
\end{tabular}

\section{Appendix 3: Directional effects of motivation and degree of privilege of EIAs}

(GLS estimation using three sets of fixed effects)

\begin{tabular}{|c|c|c|c|c|c|c|c|c|c|}
\hline \multirow{2}{*}{$\begin{array}{c}\text { Independent } \\
\text { variables }\end{array}$} & \multicolumn{3}{|c|}{ Set (1) } & \multicolumn{3}{|c|}{ Set (2) } & \multicolumn{3}{|c|}{ Set (3) } \\
\hline & $\mathbf{X}$ & IM & EM & $\mathbf{X}$ & IM & EM & $\mathbf{X}$ & IM & EM \\
\hline \multicolumn{10}{|c|}{ ExtraEU imports } \\
\hline TWPTA & $\begin{array}{c}-0.15 \\
(0.161)\end{array}$ & \begin{tabular}{|c|}
$-0.37 * *$ \\
$(0.159)$
\end{tabular} & $\begin{array}{c}0.22 \\
(0.128)\end{array}$ & $\begin{array}{c}-0.2 \\
(0.149)\end{array}$ & $\begin{array}{l}-0.37^{* *} \\
(0.154)\end{array}$ & $\begin{array}{c}0.18 \\
(0.126)\end{array}$ & \begin{tabular}{c}
-0.15 \\
$(0.149)$ \\
\hdashline
\end{tabular} & $\begin{array}{c}-0.31 \\
(0.205)\end{array}$ & $\begin{array}{c}0.16 \\
(0.164)\end{array}$ \\
\hline $\operatorname{Lag} 5$ & & & & $\begin{array}{c}0.16 \\
(0.124)\end{array}$ & $\begin{array}{c}-0.02 \\
(0.111)\end{array}$ & $\begin{array}{l}0.18^{* *} \\
(0.069)\end{array}$ & $\begin{array}{c}0.15 \\
(0.150)\end{array}$ & $\begin{array}{c}-0.08 \\
(0.126)\end{array}$ & $\begin{array}{l}0.23^{* *} \\
(0.090)\end{array}$ \\
\hline Lag10 & & & & & & & $\begin{array}{c}0.05 \\
(0.165)\end{array}$ & $\begin{array}{c}0.07 \\
(0.114)\end{array}$ & $\begin{array}{c}-0.02 \\
(0.106)\end{array}$ \\
\hline$S A A$ & $\begin{array}{l}-0.67 * * \\
(0.282)\end{array}$ & $\begin{array}{l}-0.81 * * * \\
(0.272)\end{array}$ & $\begin{array}{l}0.14^{* * *} \\
(0.071)\end{array}$ & $\begin{array}{c}-0.73 * * * \\
(0.350)\end{array}$ & $\begin{array}{l}0.88^{* * *} \\
(0.291)\end{array}$ & $\begin{array}{c}0.16 \\
(0.093)\end{array}$ & $\begin{array}{l}-0.66^{* * *} \\
(0.352)\end{array}$ & $\begin{array}{l}-0.83^{* *} \\
(0.298)\end{array}$ & $\begin{array}{c}0.17 \\
(0.109)\end{array}$ \\
\hline Lag 5 & & & & $\begin{array}{c}-0.1 \\
(0.228)\end{array}$ & $\begin{array}{l}-0.38^{* *} \\
(0.159)\end{array}$ & $\begin{array}{l}0.27 * * \\
(0.124)\end{array}$ & $\begin{array}{c}-0.11 \\
(0.257)\end{array}$ & $\begin{array}{l}-0.40 * * \\
(0.173)\end{array}$ & $\begin{array}{l}0.30 * * * \\
(0.139)\end{array}$ \\
\hline$A S S$ & $\begin{array}{l}0.27^{* *} \\
(0.110)\end{array}$ & $\begin{array}{l}0.31 * * \\
(0.120)\end{array}$ & $\begin{array}{c}-0.04 \\
(0.082)\end{array}$ & $\begin{array}{l}0.27^{*} * \\
(0.108)\end{array}$ & $\begin{array}{l}0.32^{* *} \\
(0.125)\end{array}$ & $\begin{array}{c}-0.04 \\
(0.085)\end{array}$ & $\begin{array}{l}0.29^{* * *} \\
(0.134)\end{array}$ & $\begin{array}{l}0.27^{* * *} \\
(0.155)\end{array}$ & $\begin{array}{c}0.01 \\
(0.088)\end{array}$ \\
\hline Lag5 & & & & $\begin{array}{c}0.15 \\
(0.089)\end{array}$ & $\begin{array}{c}-0.04 \\
(0.098)\end{array}$ & $\begin{array}{l}0.19^{* * *} \\
(0.042)\end{array}$ & $\begin{array}{l}0.19^{* * *} \\
(0.094)\end{array}$ & $\begin{array}{c}-0.04 \\
(0.105)\end{array}$ & $\begin{array}{l}0.23 * * * \\
(0.055)\end{array}$ \\
\hline $\operatorname{Lag} 10$ & & & & & & & $\begin{array}{c}0.17 \\
(0.121)\end{array}$ & $\begin{array}{c}0.06 \\
(0.132)\end{array}$ & $\begin{array}{c}0.11 \\
(0.077)\end{array}$ \\
\hline EUFTA & $\begin{array}{l}0.49^{* *} \\
(0.228)\end{array}$ & $\begin{array}{c}0.01 \\
(0.213)\end{array}$ & $\begin{array}{l}0.48^{* *} \\
(0.206)\end{array}$ & $\begin{array}{l}0.47 * * * \\
(0.229)\end{array}$ & $\begin{array}{c}0.00 \\
(0.216)\end{array}$ & $\begin{array}{l}0.47^{* *} \\
(0.205)\end{array}$ & $\begin{array}{l}0.52^{* * *} \\
(0.276)\end{array}$ & $\begin{array}{c}0.12 \\
(0.258)\end{array}$ & $\begin{array}{l}0.40^{* * *} \\
(0.218)\end{array}$ \\
\hline $\operatorname{Lag} 5$ & & & & $\begin{array}{c}0.03 \\
(0.089)\end{array}$ & $\begin{array}{c}-0.13 \\
(0.103)\end{array}$ & $\begin{array}{c}0.16 \\
(0.096)\end{array}$ & $\begin{array}{c}0.07 \\
(0.100)\end{array}$ & $\begin{array}{c}-0.14 \\
(0.142)\end{array}$ & $\begin{array}{c}0.2 \\
(0.126)\end{array}$ \\
\hline $\operatorname{Lag} 10$ & & & & & & & $\begin{array}{c}-0.05 \\
(0.105) \\
\end{array}$ & $\begin{array}{c}0.00 \\
(0.106)\end{array}$ & $\begin{array}{c}-0.05 \\
(0.075)\end{array}$ \\
\hline$E U C U$ & $\begin{array}{c}0.14 \\
(0.105)\end{array}$ & $\begin{array}{c}-0.02 \\
(0.106)\end{array}$ & $\begin{array}{c}0.16 \\
(0.102)\end{array}$ & $\begin{array}{c}0.14 \\
(0.108) \\
\end{array}$ & $\begin{array}{c}0.00 \\
(0.107)\end{array}$ & $\begin{array}{c}0.13 \\
(0.107)\end{array}$ & $\begin{array}{c}0.14 \\
(0.098)\end{array}$ & $\begin{array}{c}0.04 \\
(0.118)\end{array}$ & $\begin{array}{c}0.11 \\
(0.113)\end{array}$ \\
\hline $\operatorname{Lag} 5$ & & & & $\begin{array}{c}0.04 \\
(0.086)\end{array}$ & $\begin{array}{c}-0.13 \\
(0.086)\end{array}$ & $\begin{array}{l}0.17 * * \\
(0.066)\end{array}$ & $\begin{array}{c}0.03 \\
(0.097)\end{array}$ & $\begin{array}{c}-0.13 \\
(0.102)\end{array}$ & $\begin{array}{l}0.16^{* * *} \\
(0.079)\end{array}$ \\
\hline Lag10 & & & & & & & $\begin{array}{c}-0.08 \\
(0.111)\end{array}$ & $\begin{array}{c}0.10 \\
(0.112)\end{array}$ & $\begin{array}{c}-0.18 \\
(0.113)\end{array}$ \\
\hline
\end{tabular}


(continued)

\begin{tabular}{|c|c|c|c|c|c|c|c|c|c|}
\hline \multirow{2}{*}{$\begin{array}{c}\text { Independent } \\
\text { variables }\end{array}$} & \multicolumn{3}{|c|}{ Set (1) } & \multicolumn{3}{|c|}{ Set (2) } & \multicolumn{3}{|c|}{ Set (3) } \\
\hline & $\mathrm{X}$ & IM & EM & $\mathbf{X}$ & IM & EM & $\mathbf{X}$ & IM & EM \\
\hline \multicolumn{10}{|c|}{ ExtraEU exports } \\
\hline TWPTA & \begin{tabular}{|c|}
0.14 \\
$(0.250)$
\end{tabular} & \begin{tabular}{|c|}
$0.37 * * *$ \\
$(0.215)$ \\
\end{tabular} & $\begin{array}{c}-0.23 \\
(0.169)\end{array}$ & $\begin{array}{c}0.08 \\
(0.244)\end{array}$ & \begin{tabular}{c|c|}
0.27 \\
$(0.202)$ \\
\end{tabular} & \begin{tabular}{|c|}
-0.19 \\
$(0.179)$
\end{tabular} & $\begin{array}{c}0.19 \\
-0.261)\end{array}$ & $\begin{array}{c}0.34 \\
(0.197)\end{array}$ & $\begin{array}{c}-0.16 \\
(0.218)\end{array}$ \\
\hline $\operatorname{Lag} 5$ & & & & $\begin{array}{c}0.18 \\
(0.197)\end{array}$ & $\begin{array}{l}0.24 * * * \\
(0.136)\end{array}$ & $\begin{array}{c}-0.06 \\
(0.144)\end{array}$ & $\begin{array}{c}0.26 \\
(0.239)\end{array}$ & $\begin{array}{c}0.28 \\
(0.186)\end{array}$ & $\begin{array}{c}-0.02 \\
(0.176)\end{array}$ \\
\hline Lag10 & & & & & & & $\begin{array}{c}0.03 \\
(0.177)\end{array}$ & $\begin{array}{c}0.01 \\
(0.166)\end{array}$ & $\begin{array}{c}0.02 \\
(0.165)\end{array}$ \\
\hline$S A A$ & $\begin{array}{c}0.56 \\
(0.345)\end{array}$ & $\begin{array}{c}0.18 \\
(0.411)\end{array}$ & $\begin{array}{l}0.38^{* * *} \\
(0.115)\end{array}$ & $\begin{array}{c}0.49 \\
(0.310)\end{array}$ & $\begin{array}{c}0.1 \\
(0.415)\end{array}$ & $\begin{array}{l}0.39^{* *} \\
(0.162) \\
\end{array}$ & $\begin{array}{c}0.46 \\
(0.335)\end{array}$ & $\begin{array}{c}0.05 \\
(0.431)\end{array}$ & $\begin{array}{c}0.41^{* *} \\
(0.162)\end{array}$ \\
\hline $\operatorname{Lag} 5$ & & & & $\begin{array}{c}-0.28 \\
(0.234)\end{array}$ & $\begin{array}{l}-0.35^{* * *} \\
(0.185)\end{array}$ & $\begin{array}{c}0.07 \\
(0.162)\end{array}$ & $\begin{array}{c}-0.35 \\
(0.232)\end{array}$ & $\begin{array}{l}-0.43 * * \\
(0.195)\end{array}$ & $\begin{array}{c}0.08 \\
(0.151)\end{array}$ \\
\hline$A S S$ & $\begin{array}{l}0.30^{* * *} \\
(0.149)\end{array}$ & $\begin{array}{l}0.32 * * \\
(0.146)\end{array}$ & $\begin{array}{c}-0.02 \\
(0.114)\end{array}$ & $\begin{array}{l}0.35^{* *} \\
(0.159)\end{array}$ & $\begin{array}{c}0.35^{* *} \\
(0.149)\end{array}$ & $\begin{array}{c}0 \\
(0.117) \\
\end{array}$ & $\begin{array}{c}0.24 \\
(0.180)\end{array}$ & $\begin{array}{c}0.16 \\
(0.126)\end{array}$ & $\begin{array}{c}0.07 \\
(0.117)\end{array}$ \\
\hline $\operatorname{Lag} 5$ & & & & $\begin{array}{c}0.19 \\
(0.122)\end{array}$ & $\begin{array}{c}0.06 \\
(0.111)\end{array}$ & $\begin{array}{c}0.13 \\
(0.091)\end{array}$ & $\begin{array}{c}0.13 \\
(0.148)\end{array}$ & $\begin{array}{c}0.00 \\
(0.129)\end{array}$ & $\begin{array}{c}0.14 \\
(0.094)\end{array}$ \\
\hline Lag10 & & & & & & & $\begin{array}{c}-0.18 \\
(0.177)\end{array}$ & $\begin{array}{c}-0.27 \\
(0.161)\end{array}$ & $\begin{array}{c}0.08 \\
(0.127)\end{array}$ \\
\hline EUFTA & $\begin{array}{c}0.93 * * \\
(0.361)\end{array}$ & $\begin{array}{c}-0.58^{* *} \\
(0.269)\end{array}$ & $\begin{array}{l}1.51^{* * *} \\
(0.476)\end{array}$ & $\begin{array}{l}0.93 * * \\
(0.351)\end{array}$ & $\begin{array}{l}-0.59^{* *} \\
(0.260)\end{array}$ & $\begin{array}{l}1.52 * * * \\
(0.442)\end{array}$ & $\begin{array}{l}0.91 * * * \\
(0.299)\end{array}$ & $\begin{array}{l}-0.38^{* *} \\
(0.136)\end{array}$ & $\begin{array}{l}1.29 * * * \\
(0.277)\end{array}$ \\
\hline $\operatorname{Lag} 5$ & & & & $\begin{array}{l}0.30^{* * *} \\
(0.154)\end{array}$ & $\begin{array}{l}-0.29^{* *} \\
(0.134)\end{array}$ & $\begin{array}{l}0.59 * * * \\
(0.165)\end{array}$ & $\begin{array}{l}0.41^{* *} \\
(0.179)\end{array}$ & $\begin{array}{c}-0.26 \\
(0.168)\end{array}$ & $\begin{array}{l}0.67 * * * \\
(0.174)\end{array}$ \\
\hline Lag10 & & & & & & & $\begin{array}{l}-0.39 * * \\
(0.166)\end{array}$ & $\begin{array}{c}-0.12 \\
(0.185)\end{array}$ & $\begin{array}{c}-0.27 \\
(0.234)\end{array}$ \\
\hline$E U C U$ & $\begin{array}{l}0.43 * * * \\
(0.151)\end{array}$ & $\begin{array}{l}-0.26^{* * *} \\
(0.154)\end{array}$ & $\begin{array}{l}0.69^{* * *} \\
(0.164)\end{array}$ & $\begin{array}{l}0.32 * * \\
(0.143)\end{array}$ & $\begin{array}{c}-0.25 \\
(0.158)\end{array}$ & $\begin{array}{l}0.56^{* * *} \\
(0.173)\end{array}$ & $\begin{array}{l}0.37^{* * *} \\
(0.201)\end{array}$ & $\begin{array}{c}-0.15 \\
(0.180)\end{array}$ & $\begin{array}{l}0.53^{* *} \\
(0.226)\end{array}$ \\
\hline $\operatorname{Lag} 5$ & & & & $\begin{array}{l}0.39 * * * \\
(0.108)\end{array}$ & $\begin{array}{c}0.05 \\
(0.112)\end{array}$ & $\begin{array}{l}0.34^{* * *} \\
(0.111)\end{array}$ & $\begin{array}{l}0.39^{* * *} \\
(0.115)\end{array}$ & $\begin{array}{c}0.08 \\
(0.118)\end{array}$ & $\begin{array}{c}0.32 * * \\
(0.114)\end{array}$ \\
\hline Lag10 & & & & & & & $\begin{array}{c}-0.15 \\
(0.190)\end{array}$ & $\begin{array}{c}0.01 \\
(0.200)\end{array}$ & $\begin{array}{c}-0.15 \\
(0.225) \\
\end{array}$ \\
\hline Observations & 182,314 & 182,314 & 182,314 & 162,976 & 162,976 & 162,976 & 134,031 & 134,031 & 134,031 \\
\hline
\end{tabular}

(Note) (i) Estimation using the log of trade (X), the log of the Intensive Margin (IM) or the log of the Extensive Margin (EM), respectively, as the dependent variable. With TWPTA: Two-way Preferential Trade Agreement, SAA: Stabilisation and Association Agreement, ASS: Association Agreement, EUFTA: EU Free Trade Agreement, EUCU: EU Customs Union, and Lag5 and Lag10 the 5- and 10-year lagged value of the respective variable. Because most SAAs have only entered into force recently, lag 10 is omitted. Other captures all EIAs not captured by the GSP, EBA, TWPTA, SAA, ASS, EUFTA, and EUCU dummies.

(ii) For a list of agreements per category, see Appendix 1. See text for a definition of each agreement category.

(iii) Estimation includes country-year and pair fixed effects. Standard errors clustered on country pair and year under the coefficient. ${ }^{* *} p<0.01,{ }^{* *} p<0.05$, and ${ }^{*} p<0.1$. 


\section{Appendix 4: Effects per agreement}

(GLS estimation using three sets of fixed effects)

\begin{tabular}{|c|c|c|c|}
\hline Country name & $\mathbf{X}$ & IM & EM \\
\hline$O C T$ & $\begin{array}{c}-0.06 \\
(0.142)\end{array}$ & $\begin{array}{c}-0.50 * * * \\
(0.152)\end{array}$ & $\begin{array}{l}0.44 * * \\
(0.170)\end{array}$ \\
\hline Egypt & $\begin{array}{c}-0.09 \\
(0.192)\end{array}$ & $\begin{array}{c}-0.27 \\
(0.163)\end{array}$ & $\begin{array}{l}0.18^{* *} \\
(0.086)\end{array}$ \\
\hline Iceland & $\begin{array}{c}0.63 * * * \\
(0.195)\end{array}$ & $\begin{array}{c}0.20 \\
(0.182)\end{array}$ & $\begin{array}{l}0.42^{* *} \\
(0.175)\end{array}$ \\
\hline Norway & $\begin{array}{c}-0.01 \\
(0.134)\end{array}$ & $\begin{array}{c}-0.18 \\
(0.128)\end{array}$ & $\begin{array}{c}0.17 \\
(0.103)\end{array}$ \\
\hline Algeria & $\begin{array}{c}0.71 \\
(0.964)\end{array}$ & $\begin{array}{c}0.10 \\
(0.564)\end{array}$ & $\begin{array}{c}0.61 \\
(0.444)\end{array}$ \\
\hline Andorra & $\begin{array}{c}-0.05 \\
(0.312)\end{array}$ & $\begin{array}{c}-0.26 \\
(0.369)\end{array}$ & $\begin{array}{c}0.20 \\
(0.434)\end{array}$ \\
\hline Turkey & $\begin{array}{l}0.40^{* *} \\
(0.169)\end{array}$ & $\begin{array}{c}0.10 \\
(0.167)\end{array}$ & $\begin{array}{c}0.30 * * * \\
(0.083)\end{array}$ \\
\hline Faroe & $\begin{array}{c}1.53 * * * \\
(0.385)\end{array}$ & $\begin{array}{l}-0.62 * \\
(0.341)\end{array}$ & $\begin{array}{c}2.15 * * * \\
(0.531)\end{array}$ \\
\hline Palestine & $\begin{array}{l}1.56 * * * \\
(0.382)\end{array}$ & $\begin{array}{c}1.03 \\
(0.650)\end{array}$ & $\begin{array}{c}0.53 \\
(0.637)\end{array}$ \\
\hline Macedonia & $\begin{array}{l}0.45^{* *} \\
(0.204)\end{array}$ & $\begin{array}{c}0.38 \\
(0.245)\end{array}$ & $\begin{array}{c}0.07 \\
(0.138)\end{array}$ \\
\hline Jordan & $\begin{array}{c}0.37^{*} \\
(0.200)\end{array}$ & $\begin{array}{c}-0.04 \\
(0.162)\end{array}$ & $\begin{array}{c}0.41 * * * \\
(0.079)\end{array}$ \\
\hline San Marino & $\begin{array}{c}0.84 * * * \\
(0.272)\end{array}$ & $\begin{array}{c}-0.21 \\
(0.264)\end{array}$ & $\begin{array}{c}1.05 * * * \\
(0.250)\end{array}$ \\
\hline Chile & $\begin{array}{c}-0.03 \\
(0.195)\end{array}$ & $\begin{array}{c}-0.07 \\
(0.150)\end{array}$ & $\begin{array}{c}0.04 \\
(0.083)\end{array}$ \\
\hline Lebanon & $\begin{array}{l}0.47 * * \\
(0.222)\end{array}$ & $\begin{array}{c}-0.06 \\
(0.190)\end{array}$ & $\begin{array}{c}0.53^{* * *} \\
(0.092)\end{array}$ \\
\hline Albania & $\begin{array}{c}-0.89 * * * \\
(0.123)\end{array}$ & $\begin{array}{c}-0.42 * * * \\
(0.136)\end{array}$ & $\begin{array}{c}-0.47 * * \\
(0.198)\end{array}$ \\
\hline Israel & $\begin{array}{c}0.40 * * * \\
(0.118)\end{array}$ & $\begin{array}{c}0.05 \\
(0.109)\end{array}$ & $\begin{array}{c}0.35 * * * \\
(0.074)\end{array}$ \\
\hline Morocco & $\begin{array}{c}0.24 \\
(0.182)\end{array}$ & $\begin{array}{c}0.72 * * * \\
(0.194)\end{array}$ & $\begin{array}{c}-0.48 * * * \\
(0.147)\end{array}$ \\
\hline Tunisia & $\begin{array}{c}0.37^{*} \\
(0.208)\end{array}$ & $\begin{array}{c}0.87 * * * \\
(0.186)\end{array}$ & $\begin{array}{c}-0.49 * * * \\
(0.132)\end{array}$ \\
\hline Mexico & $\begin{array}{c}0.14 \\
(0.177)\end{array}$ & $\begin{array}{c}0.02 \\
(0.177)\end{array}$ & $\begin{array}{c}0.12 \\
(0.077)\end{array}$ \\
\hline
\end{tabular}


(continued)

\begin{tabular}{|l|c|c|c|}
\hline Country name & $\mathbf{X}$ & IM & EM \\
\hline South Africa & $0.28^{*}$ & 0.10 & $0.18^{* * *}$ \\
$(0.159)$ & $(0.140)$ & $(0.051)$ \\
\hline \multirow{2}{*}{ Control } & 0.00 & $-0.14^{* *}$ & $0.14^{* * *}$ \\
& $(0.045)$ & $(0.064)$ & $(0.047)$ \\
\hline Observations & 182,314 & 182,314 & 182,314 \\
\hline
\end{tabular}

(Note) (i) Estimation using the log of trade (X), the log of the Intensive Margin (IM) or the log of the Extensive Margin (EM), respectively, as the dependent variable. The country name denotes the trade agreement between the EU and the respective country, while Control absorbs all other EIAs.

(ii) Estimation includes country-year and pair fixed effects. Standard errors clustered on country pair and year under the coefficient. $* * * p<0.01, * * p<0.05$, and $* p<0.1$. 


\section{Appendix 5: Estimation of the baseline model}

(using fourth differences)

\begin{tabular}{|c|c|c|c|c|c|c|c|c|c|}
\hline \multirow{2}{*}{$\begin{array}{l}\text { Independent } \\
\text { variables }\end{array}$} & \multicolumn{3}{|c|}{ Set (1) } & \multicolumn{3}{|c|}{ Set (2) } & \multicolumn{3}{|c|}{ Set (3) } \\
\hline & $\mathbf{X}$ & IM & EM & $\mathbf{X}$ & IM & EM & $\mathbf{X}$ & IM & EM \\
\hline$\Delta_{4} P T A$ & $\begin{array}{c}0.04 \\
(0.059)\end{array}$ & $\begin{array}{c}-0.12 \\
(0.070)\end{array}$ & $\begin{array}{l}0.16^{* * *} \\
(0.040)\end{array}$ & $\begin{array}{c}0.06 \\
(0.057)\end{array}$ & $\begin{array}{c}-0.12 * \\
(0.068)\end{array}$ & $\begin{array}{l}0.18^{* * *} \\
(0.040)\end{array}$ & $\begin{array}{c}0.11^{*} \\
(0.060)\end{array}$ & $\begin{array}{c}-0.08 \\
(0.065)\end{array}$ & $\begin{array}{c}0.19^{* * * *} \\
(0.038)\end{array}$ \\
\hline $\operatorname{Lag} 5$ & & & & $\begin{array}{c}0.05 \\
(0.039)\end{array}$ & $\begin{array}{c}-0.02 \\
(0.045)\end{array}$ & $\begin{array}{c}0.08^{*} \\
(0.039)\end{array}$ & $\begin{array}{c}0.05 \\
(0.046)\end{array}$ & $\begin{array}{c}-0.02 \\
(0.054)\end{array}$ & $\begin{array}{c}0.08 \\
(0.044)\end{array}$ \\
\hline Lag10 & & & & & & & $\begin{array}{c}0.02 \\
(0.034)\end{array}$ & $\begin{array}{c}0.00 \\
(0.051)\end{array}$ & $\begin{array}{c}0.02 \\
(0.036)\end{array}$ \\
\hline$\Delta_{4} F T A$ & $\begin{array}{c}0.09 \\
(0.070)\end{array}$ & $\begin{array}{c}-0.01 \\
-0.059)\end{array}$ & $\begin{array}{c}0.1 \\
(0.066)\end{array}$ & $\begin{array}{c}0.11 \\
(0.071)\end{array}$ & $\begin{array}{c}-0.01 \\
(0.063)\end{array}$ & $\begin{array}{c}0.12 \\
(0.073)\end{array}$ & $\begin{array}{l}0.20 * * \\
(0.073)\end{array}$ & $\begin{array}{c}0.02 \\
(0.071)\end{array}$ & $\begin{array}{l}0.18^{* *} \\
(0.062)\end{array}$ \\
\hline $\operatorname{Lag} 5$ & & & & $\begin{array}{c}0.07^{*} \\
(0.039)\end{array}$ & $\begin{array}{c}-0.02 \\
(0.066)\end{array}$ & $\begin{array}{c}0.09^{*} \\
(0.053)\end{array}$ & $\begin{array}{l}0.11 * * \\
(0.044)\end{array}$ & \begin{tabular}{c|}
-0.03 \\
$(0.075)$
\end{tabular} & $\begin{array}{c}0.13^{* *} \\
(0.058)\end{array}$ \\
\hline Lag10 & & & & & & & $\begin{array}{c}0.02 \\
(0.037)\end{array}$ & $\begin{array}{c}0.02 \\
(0.044)\end{array}$ & $\begin{array}{c}-0.01 \\
(0.035)\end{array}$ \\
\hline$\Delta_{4} C U$ & $\begin{array}{l}0.30^{* *} \\
(0.117)\end{array}$ & $\begin{array}{c}-0.11 \\
(0.067)\end{array}$ & $\begin{array}{l}0.41^{* * *} \\
(0.132)\end{array}$ & $\begin{array}{l}0.32 * * \\
(0.118)\end{array}$ & $\begin{array}{c}-0.1 \\
(0.066)\end{array}$ & $\begin{array}{l}0.42 * * * \\
(0.136)\end{array}$ & $\begin{array}{c}0.41 * * * \\
(0.103)\end{array}$ & $\begin{array}{c}-0.04 \\
(0.075)\end{array}$ & $\begin{array}{c}0.46^{* * * *} \\
(0.111)\end{array}$ \\
\hline $\operatorname{Lag} 5$ & & & & $\begin{array}{l}0.10^{* *} \\
(0.042)\end{array}$ & $\begin{array}{c}0.04 \\
(0.064)\end{array}$ & $\begin{array}{c}0.05 \\
(0.057)\end{array}$ & $\begin{array}{l}0.12 * * \\
(0.050)\end{array}$ & $\begin{array}{c}0.04 \\
(0.079)\end{array}$ & $\begin{array}{c}0.08 \\
(0.072)\end{array}$ \\
\hline Lag10 & & & & & & & $\begin{array}{c}-0.09 \\
(0.066)\end{array}$ & $\begin{array}{c}-0.04 \\
(0.100)\end{array}$ & $\begin{array}{c}-0.05 \\
(0.094)\end{array}$ \\
\hline \multicolumn{10}{|l|}{ Total ATE } \\
\hline$\Delta_{4} P T A$ & & & & & & & $\begin{array}{l}0.18 * * \\
(0.071)\end{array}$ & $\begin{array}{c}-0.10 \\
(0.074)\end{array}$ & $\begin{array}{c}0.28 * * * \\
(0.050)\end{array}$ \\
\hline$\Delta_{4} F T A$ & & & & & & & $\begin{array}{c}0.32 * * * \\
(0.096)\end{array}$ & \begin{tabular}{c|}
0.02 \\
$(0.135)$
\end{tabular} & $\begin{array}{l}0.30^{* *} \\
(0.120)\end{array}$ \\
\hline$\Delta_{4} C U$ & & & & & & & $\begin{array}{l}0.44 * * \\
(0.161)\end{array}$ & $\begin{array}{c}-0.05 \\
(0.179)\end{array}$ & $\begin{array}{l}0.49^{* *} \\
(0.214)\end{array}$ \\
\hline Observations & 138,266 & 138,266 & 138,266 & 119,478 & 119,478 & 119,478 & 91,759 & 91,759 & 91,759 \\
\hline
\end{tabular}

(Note) (i) Estimation using the differenced log of trade (X), the differenced log of the Intensive Margin (IM) or the differenced log of the Extensive Margin (EM), respectively, as the dependent variable. With $\Delta_{4}$ denoting fourth differences, PTA Preferential Trade Agreement, FTA Free Trade Agreement, CU Customs Union and Common Market, Lag5 and Lag10 the 5- and 10-year lagged value of the respective variable and ATE total Average Treatment Effect.

(ii) Standard errors clustered on country pair and year under the coefficient. $* * * p<0.01, * * p<0.05$, and $* p<0.1$. ATEs are computed using a two-tailed joint significance test. 


\section{Appendix 6: Estimation of the baseline model}

(using a random growth model)

\begin{tabular}{|c|c|c|c|c|c|c|c|c|c|}
\hline \multirow{2}{*}{$\begin{array}{l}\text { Independent } \\
\text { variables }\end{array}$} & \multicolumn{3}{|c|}{ Set (1) } & \multicolumn{3}{|c|}{ Set (2) } & \multicolumn{3}{|c|}{ Set (3) } \\
\hline & $X$ & IM & EM & $\mathbf{X}$ & IM & EM & $\mathbf{X}$ & IM & EM \\
\hline$\Delta_{4} P T A$ & $\begin{array}{c}0.04 \\
(0.073)\end{array}$ & $\begin{array}{c}-0.1 \\
(0.086)\end{array}$ & $\begin{array}{l}0.14 * * * \\
(0.051)\end{array}$ & $\begin{array}{c}0.06 \\
(0.075)\end{array}$ & \begin{tabular}{c|}
-0.11 \\
$(0.087)$
\end{tabular} & $\begin{array}{l}0.17 * * * \\
(0.055)\end{array}$ & $\begin{array}{c}0.10 \\
(0.086)\end{array}$ & $\begin{array}{c}-0.08 \\
(0.089)\end{array}$ & $\begin{array}{l}0.17 * * \\
(0.064)\end{array}$ \\
\hline $\operatorname{Lag} 5$ & & & & $\begin{array}{c}0.03 \\
(0.042)\end{array}$ & $\begin{array}{c}-0.02 \\
(0.058)\end{array}$ & $\begin{array}{c}0.06 \\
(0.051)\end{array}$ & $\begin{array}{c}-0.02 \\
(0.050)\end{array}$ & $\begin{array}{c}-0.06 \\
(0.070)\end{array}$ & $\begin{array}{c}0.04 \\
(0.053)\end{array}$ \\
\hline Lag10 & & & & & & & $\begin{array}{c}-0.07 \\
(0.050)\end{array}$ & $\begin{array}{c}-0.05 \\
(0.066)\end{array}$ & $\begin{array}{c}-0.02 \\
(0.057)\end{array}$ \\
\hline$\Delta_{4} F T A$ & $\begin{array}{c}0.04 \\
(0.093)\end{array}$ & $\begin{array}{c}-0.01 \\
(0.084)\end{array}$ & \begin{tabular}{|c|c|}
0.04 \\
$(0.069)$
\end{tabular} & $\begin{array}{c}0.06 \\
(0.099)\end{array}$ & \begin{tabular}{c|}
0.01 \\
$(0.084)$
\end{tabular} & $\begin{array}{c}0.05 \\
(0.075)\end{array}$ & $\begin{array}{c}0.11 \\
(0.113)\end{array}$ & $\begin{array}{c}0.03 \\
(0.095)\end{array}$ & $\begin{array}{c}0.08 \\
(0.075)\end{array}$ \\
\hline $\operatorname{Lag} 5$ & & & & $\begin{array}{c}0.04 \\
(0.035)\end{array}$ & \begin{tabular}{c|c}
0.04 & \\
$(0.042)$ &
\end{tabular} & $\begin{array}{c}0 \\
(0.042)\end{array}$ & $\begin{array}{c}0.06 \\
(0.046)\end{array}$ & $\begin{array}{c}0.03 \\
(0.056)\end{array}$ & $\begin{array}{c}0.02 \\
(0.053)\end{array}$ \\
\hline Lag10 & & & & & & & $\begin{array}{c}0 \\
(0.047)\end{array}$ & $\begin{array}{c}0.06 \\
(0.038)\end{array}$ & $\begin{array}{c}-0.06 \\
(0.036)\end{array}$ \\
\hline$\Delta_{4} C U$ & $\begin{array}{c}0.2 \\
(0.134)\end{array}$ & $\begin{array}{l}-0.18^{*} \\
(0.096)\end{array}$ & \begin{tabular}{l|l}
$0.38^{* *}$ & \\
$(0.152)$ &
\end{tabular} & $\begin{array}{c}0.21 \\
(0.144)\end{array}$ & \begin{tabular}{c|}
-0.16 \\
$(0.097)$
\end{tabular} & $\begin{array}{l}0.37^{* *} \\
(0.168)\end{array}$ & $\begin{array}{c}0.29^{*} \\
(0.148)\end{array}$ & $\begin{array}{c}-0.08 \\
(0.113)\end{array}$ & $\begin{array}{l}0.37^{* *} \\
(0.146)\end{array}$ \\
\hline Lag5 & & & & $\begin{array}{c}0.02 \\
(0.062)\end{array}$ & $\begin{array}{c}0.05 \\
(0.060)\end{array}$ & $\begin{array}{c}-0.03 \\
(0.080)\end{array}$ & $\begin{array}{c}0.00 \\
(0.066)\end{array}$ & $\begin{array}{c}0.06 \\
(0.080)\end{array}$ & $\begin{array}{c}-0.06 \\
(0.091)\end{array}$ \\
\hline Lag10 & & & & & & & $\begin{array}{c}-0.12 \\
(0.080)\end{array}$ & $\begin{array}{c}-0.02 \\
(0.100)\end{array}$ & $\begin{array}{c}-0.1 \\
(0.088)\end{array}$ \\
\hline \multicolumn{10}{|l|}{ Total ATE } \\
\hline$\Delta_{4} P T A$ & & & & & & & $\begin{array}{c}0.01 \\
(0.109)\end{array}$ & $\begin{array}{c}-0.18 \\
(0.132)\end{array}$ & $\begin{array}{c}0.19^{*} \\
(0.105)\end{array}$ \\
\hline$\Delta_{4} F T A$ & & & & & & & $\begin{array}{c}0.17 \\
(0.163)\end{array}$ & $\begin{array}{c}0.13 \\
(0.135)\end{array}$ & $\begin{array}{c}0.05 \\
(0.118)\end{array}$ \\
\hline$\Delta_{4} C U$ & & & & & & & $\begin{array}{c}0.17 \\
(0.239)\end{array}$ & $\begin{array}{c}-0.04 \\
(0.215)\end{array}$ & $\begin{array}{c}0.21 \\
(0.208)\end{array}$ \\
\hline Obersvations & 137,907 & 137,907 & 137,907 & 119,108 & 119,108 & 119,108 & 91,371 & 91,371 & 91,371 \\
\hline
\end{tabular}

(Note) (i) Estimation using the differenced log of trade (X), the differenced log of the Intensive Margin (IM) or the differenced log of the Extensive Margin (EM), respectively, as the dependent variable. With $\Delta_{4}$ denoting fourth differences, PTA Preferential Trade Agreement, FTA Free Trade Agreement, CU Customs Union and Common Market, Lag5 and Lag10 the 5- and 10-year lagged value of the respective variable and ATE total Average Treatment Effect.

(ii) Standard errors clustered on country pair and year under the coefficient. $*^{* *} p<0.01,{ }^{* *} p<0.05$, and ${ }^{*} p<0.1$. ATEs are computed using a two-tailed joint significance test. 


\section{Appendix 7: GLS estimation of the baseline model}

(using fixed effects and a time trend)

\begin{tabular}{|c|c|c|c|c|c|c|c|c|c|}
\hline \multirow{2}{*}{$\begin{array}{l}\text { Independent } \\
\text { variables }\end{array}$} & \multicolumn{3}{|c|}{ Set (1) } & \multicolumn{3}{|c|}{ Set (2) } & \multicolumn{3}{|c|}{ Set (3) } \\
\hline & $\mathbf{X}$ & IM & EM & $X$ & IM & EM & $\mathbf{X}$ & IM & EM \\
\hline$P T A$ & $\begin{array}{c}0.01 \\
(0.072)\end{array}$ & $\begin{array}{c}-0.11 \\
(0.073)\end{array}$ & $\begin{array}{l}0.12 * * \\
(0.047)\end{array}$ & \begin{tabular}{c|c|}
0.01 \\
$(0.077)$
\end{tabular} & $\begin{array}{c}-0.11 \\
(0.075)\end{array}$ & $\begin{array}{c}0.12 * * \\
(0.048)\end{array}$ & $\begin{array}{c}0.03 \\
(0.074)\end{array}$ & $\begin{array}{c}-0.07 \\
(0.074)\end{array}$ & $\begin{array}{c}0.11^{*} \\
(0.054)\end{array}$ \\
\hline $\operatorname{Lag} 5$ & & & & \begin{tabular}{c}
0 \\
$(0.051)$ \\
\hdashline
\end{tabular} & $\begin{array}{c}-0.01 \\
(0.055)\end{array}$ & $\begin{array}{c}0.02 \\
(0.044)\end{array}$ & $\begin{array}{c}-0.06 \\
(0.061)\end{array}$ & $\begin{array}{c}-0.06 \\
(0.069)\end{array}$ & $\begin{array}{c}0.00 \\
(0.050) \\
\end{array}$ \\
\hline Lag10 & & & & & & & $\begin{array}{c}-0.08^{*} \\
(0.043)\end{array}$ & $\begin{array}{c}-0.06 \\
(0.055)\end{array}$ & $\begin{array}{c}-0.02 \\
(0.042)\end{array}$ \\
\hline FTA & $\begin{array}{c}0.07 \\
(0.094)\end{array}$ & $\begin{array}{c}-0.01 \\
(0.086)\end{array}$ & $\begin{array}{c}0.08 \\
(0.071) \\
-\end{array}$ & $\begin{array}{c}0.08 \\
(0.097)\end{array}$ & $\begin{array}{c}0.01 \\
(0.085) \\
-\end{array}$ & $\begin{array}{c}0.07 \\
(0.071)\end{array}$ & $\begin{array}{c}0.11 \\
(0.103)\end{array}$ & $\begin{array}{c}0.03 \\
(0.091)\end{array}$ & $\begin{array}{c}0.07 \\
(0.075) \\
0.07\end{array}$ \\
\hline Lag5 & & & & \begin{tabular}{c|c}
0.02 \\
$(0.041)$
\end{tabular} & $\begin{array}{c}0.05 \\
(0.039)\end{array}$ & $\begin{array}{c}-0.03 \\
(0.040)\end{array}$ & $\begin{array}{c}0.00 \\
(0.053)\end{array}$ & $\begin{array}{c}0.03 \\
(0.047)\end{array}$ & $\begin{array}{c}-0.02 \\
(0.045)\end{array}$ \\
\hline Lag10 & & & & & & & $\begin{array}{c}0.00 \\
(0.042)\end{array}$ & $\begin{array}{c}0.05 \\
(0.036)\end{array}$ & $\begin{array}{c}-0.05 \\
(0.035)\end{array}$ \\
\hline$C U$ & $\begin{array}{c}0.22 \\
(0.155)\end{array}$ & $\begin{array}{c}-0.14 \\
(0.107)\end{array}$ & $\begin{array}{c}0.36^{*} \\
(0.185)\end{array}$ & $\begin{array}{c}0.22 \\
(0.162)\end{array}$ & $\begin{array}{l}-0.13 \\
(0.104)\end{array}$ & $\begin{array}{c}0.35^{*} \\
(0.191)\end{array}$ & $\begin{array}{c}0.26 \\
(0.168)\end{array}$ & $\begin{array}{c}-0.09 \\
(0.104)\end{array}$ & $\begin{array}{c}0.35^{*} \\
(0.183)\end{array}$ \\
\hline $\operatorname{Lag} 5$ & & & & \begin{tabular}{c|}
0.02 \\
$(0.058)$
\end{tabular} & $\begin{array}{c}0.03 \\
(0.062)\end{array}$ & $\begin{array}{c}-0.02 \\
(0.064)\end{array}$ & $\begin{array}{c}-0.01 \\
(0.071)\end{array}$ & $\begin{array}{c}0.02 \\
(0.069)\end{array}$ & $\begin{array}{c}-0.03 \\
(0.069)\end{array}$ \\
\hline Lag10 & & & & & & & $\begin{array}{l}-0.12^{*} \\
(0.067)\end{array}$ & $\begin{array}{c}0.00 \\
(0.075)\end{array}$ & $\begin{array}{c}-0.12 \\
(0.070)\end{array}$ \\
\hline \multicolumn{10}{|l|}{ Total ATE } \\
\hline$P T A$ & & & & & & & $\begin{array}{l}-0.10 \\
(0.11)\end{array}$ & $\begin{array}{c}-0.18 \\
(0.119)\end{array}$ & $\begin{array}{c}0.09 \\
(0.087)\end{array}$ \\
\hline FTA & & & & & & & $\begin{array}{c}0.11 \\
(0.15)\end{array}$ & $\begin{array}{c}0.11 \\
(0.131)\end{array}$ & $\begin{array}{c}0 \\
(0.114)\end{array}$ \\
\hline$C U$ & & & & & & & $\begin{array}{c}0.13 \\
(0.238)\end{array}$ & $\begin{array}{c}-0.07 \\
(0.166)\end{array}$ & $\begin{array}{c}0.20 \\
(0.252)\end{array}$ \\
\hline Observations & 182,314 & 182,314 & 182,314 & 162,976 & 162,976 & 162,976 & 134,031 & 134,031 & 134,031 \\
\hline
\end{tabular}

(Note) (i) Estimation using the log of trade (X), the log of the Intensive Margin (IM) or the log of the Extensive Margin (EM), respectively, as the dependent variable. With PTA denoting Preferential Trade Agreement, FTA Free Trade Agreement, CU Customs Union and Common Market, Lag5 and Lag10 the 5- and 10-year lagged value of the respective variable and ATE total Average Treatment Effect.

(ii) Standard errors clustered on country pair and year under the coefficient. $* * * p<0.01, * * p<0.05$, and $*_{p}<0.1$. ATEs are computed using a two-tailed joint significance test. 